\title{
I. BATHYMETRIC, MAGNETIC, AND SEISMIC REFLECTION DATA: GLOMAR CHALLENGER, LEG 28
}

\author{
Dennis E. Hayes, ${ }^{1}$ Lamont-Doherty Geological Observatory of Columbia University, Palisades, N.Y. \\ and \\ Robert E. Wall, Submarine Geology and Geophysics Program, National Science Foundation, Washington, D.C.
}

\section{INTRODUCTION}

The underway geophysical data collected during Glomar Challenger Cruise 28 from Fremantle, Australia, to Christchurch, New Zealand, are presented in two groups of profiles (Figures 1 and 2). The first group of data consists of bathymetric and total intensity magnetic anomaly profiles displayed as a function of distance and time. The procedure used in reducing and displaying the data was that described by Talwani (1969). Local time in hours and dates are shown at the top of each figure as well as the positions where the tracks crossed integral degrees of latitude and longitude. The Leg 28 drill-site locations, conspicuous morphological features and key magnetic anomaly lineations, identified according to the system of Heirtzler et al. (1968) are labeled. For Figure 1 the uppermost profile represents depths in nominal fathoms (1/400 sec of two-way reflection time). The vertical exaggeration on these depth profiles is 100:1. The lower profile represents total intensity magnetic anomalies in gammas. The regional magnetic field has been removed using the IGRF coefficients of Cain et al. (1968). Selected positions are annotated along with course and speed made good between adjacent navigation points. The detailed listing of the navigation is available through the Deep Sea Drilling Project office at Scripps Institution of Oceanography. Distances along the track are indicated every 200 nautical miles at the bottom of each figure. The index track maps given in Figure $3 \mathrm{a}, \mathrm{b}, \mathrm{c}$ show the track location and are also annotated with hundreds of miles, drill-site locations, and selected physiographic features. The navigational information printed near the bottom of the profiles represents the speed and course made good and does not necessarily correspond with the dead-reckoned course and speed.

The second group of profiles (Figure 2) are photographic reductions of original seismic profiler reflection records. The instrumentation incorporated in the collection of these data and also that of the magnetics and depths are described briefly in the Introduction chapter of this volume. Depth scales for the seismic records are given as seconds of two-way reflection time for each profile. Note that 400 nominal fathoms approximately represent $1 \mathrm{sec}$ of two-way reflection time through the water layer. Subbottom

\footnotetext{
'Also Department of Geological Sciences, Columbia University, New York, N.Y.
}

depths can be estimated by assuming that the velocity of compressional waves in the unconsolidated sediments is approximately $2 \mathrm{~km} / \mathrm{sec}$. With this assumption, each 1.0 sec of reflection time represents $1 \mathrm{~km}$ of sediment. Selected time-date information is also shown at the bottom of each profile. In the case of the seismic profiles, the course-speed data shown on the original records are those steered and do not correspond exactly with the final adjusted courses shown on the geophysical plots. The vertical exaggeration on these profiles is approximately $30: 1$. Significant breaks in the record are indicated by the label "data gap." Hundreds of nautical miles along the track are also annotated across the bottom of the record and correspond with the distances shown on the geophysical profiles and on the index maps of Figure 3.

The seismic profiles (Figure 2) must be read from right to left on each sheet; the beginning portion of the record starts at the upper right with time and distance increasing to the left. Although the time spent on the drill sites is indicated, the precise locations of the sites on the seismic profiles are not given here; the drill sites are located on those portions of the records reproduced in the individual site report chapters of this volume.

Selected isobaths taken from Hayes and Conolly (1972), Heezen et al. (1972), and Hayes and Davey (this volume) have been incorporated into the index figures.

\section{NARRATIVE}

Between Fremantle and Site 264, Glomar Challenger proceeded southwest across the west Australian continental margin and Naturaliste Plateau where Site 264 was located. A conspicuous short-wavelength, highamplitude magnetic anomaly was associated with the upper continental slope as shown near mile 80 . The sediments of the upper continental slope are highly reflective, and very little penetration was obtained with the high-frequency, low-energy airgun source used in the seismic system. The sediments on the Naturaliste Plateau are basically transparent and correspond to about 200-400 meters in thickness, resting on a highly reflective acoustic basement surface. To the south, and seaward of the Naturaliste Plateau, the highly fractured sea-floor morphology associated with the Diamantina Fracture Zone is evident. Depths in some of the deeper valleys of this tectonically complex zone exceed 3200 fathoms. Slightly further south, the basement morphology becomes relatively smooth, and the uniform regional gradient of the sea floor (especially the basement layer) associated with the Southeast Indian Ridge is evident from mile 425 to approximately mile 1200 . 


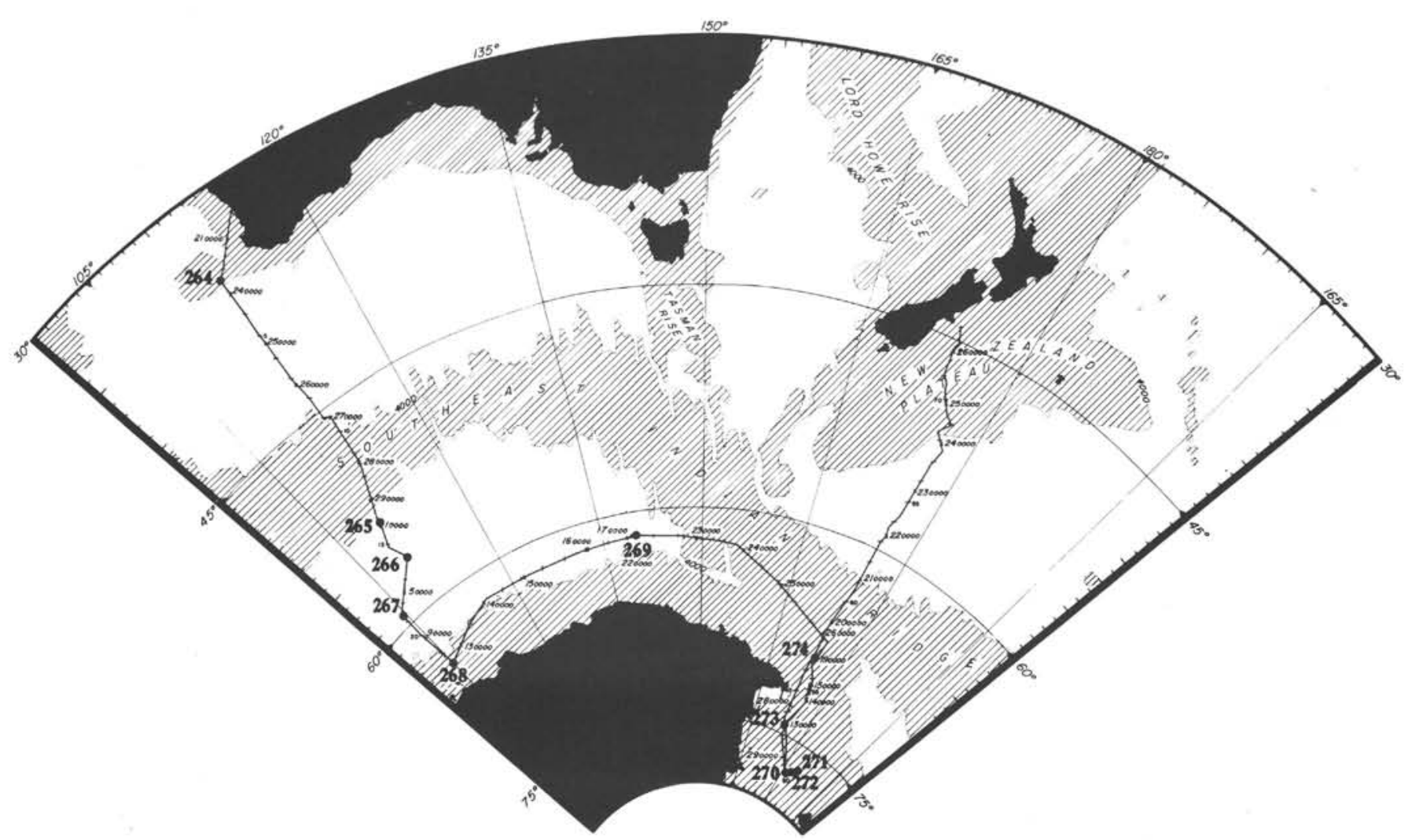

Figure 1a. Bathymetry (upper profile) in nominal fathoms (1/400 sec reflection time) and total intensity magnetic anomalies (gammas) along track of Glomar Challenger during Leg 28. Key to location is given in Figure 3.

The course on this leg of the cruise was essentially due south and the magnetic anomalies for this area, as described by Weissel and Hayes (1972), are extremely well displayed and labeled accordingly on the geophysical plots. There was no evidence that any major fracture zones were crossed along this traverse. The total sediment veneer over the north flank of the Southeast Indian Ridge is uniformly thin, thickening slightly away from the axis of the ridge in a systematic manner, probably related simply to the increasing age of the underlying crust.

Near $50^{\circ} \mathrm{S}$, close to the axis of the Southeast Indian Ridge, the Antarctic Convergence was encountered. This was accompanied by a general degradation in the weather and high sea states. From about mile 1200 until mile 1800 the quality of the seismic reflection records is extremely poor. Although the noisy record quality is no doubt partly related to the presence of rough seas, another factor is thought to be the unusual near-surface sound velocity structure south of the Antarctic convergence. This velocity structure may have degraded the signal/noise ratio by enhancing the horizontal propagation of ship and towing noise.

Although there were slight maneuverings to occupy Sites 264,265 , and 267 , the general course through this region was south, and the magnetic anomalies again are easily recognized and identified on the geophysical plots. At least one major fracture zone and perhaps other minor fracture zones were encountered along the traverse from mile 1200 to mile 2000 . The weather in the vicinity of Site 268 was extremely rough, and the sediments of the lower continental rise north of Wilkes Land were highly reflective, resulting in very poor subbottom penetration. The observed magnetic anomalies between Sites 268 and 269 (mile 2200 to mile 3200) display greatly different characteristics. Relatively lower amplitude, long-wave anomalies probably arise from the combination of two effects: (1) the ship's course was dominantly east-west in a region where magnetic lineations, if they exist, also trend east-west; and (2) this area, with crust older than anomaly $20(\sim 50$ m.y.B.P.), appears to be a region associated with a magnetically quiet zone, as described by Weissel and Hayes (1972).

Between Sites 269 and 270, the Southeast Indian Ridge was again traversed, and for small regions, specifically mile 3800 to mile 4200 , several key magnetic lineations of the Cenozoic pattern are easily recognized. The rough, step-like topography shown between miles 3500 and 3700 reflects the transiting of two or more major fracture zones; these have been well mapped in the region to the north and are indicated on Figure $3 \mathrm{~b}$, and also by Hayes and Conolly (1972). Note that in the region from about mile 3900 to mile 4200 the total blanket of sediment resting on the flank of the Southeast Indian Ridge is much thicker than its counterpart to the west even for regions representing the same crustal age (about 30-40 m.y.B.P.). The graben-like feature shown at mile 4440 is probably the extension of the graben discussed by Hayes and Davey (this volume). For a detailed description of the geophysical characteristics of 


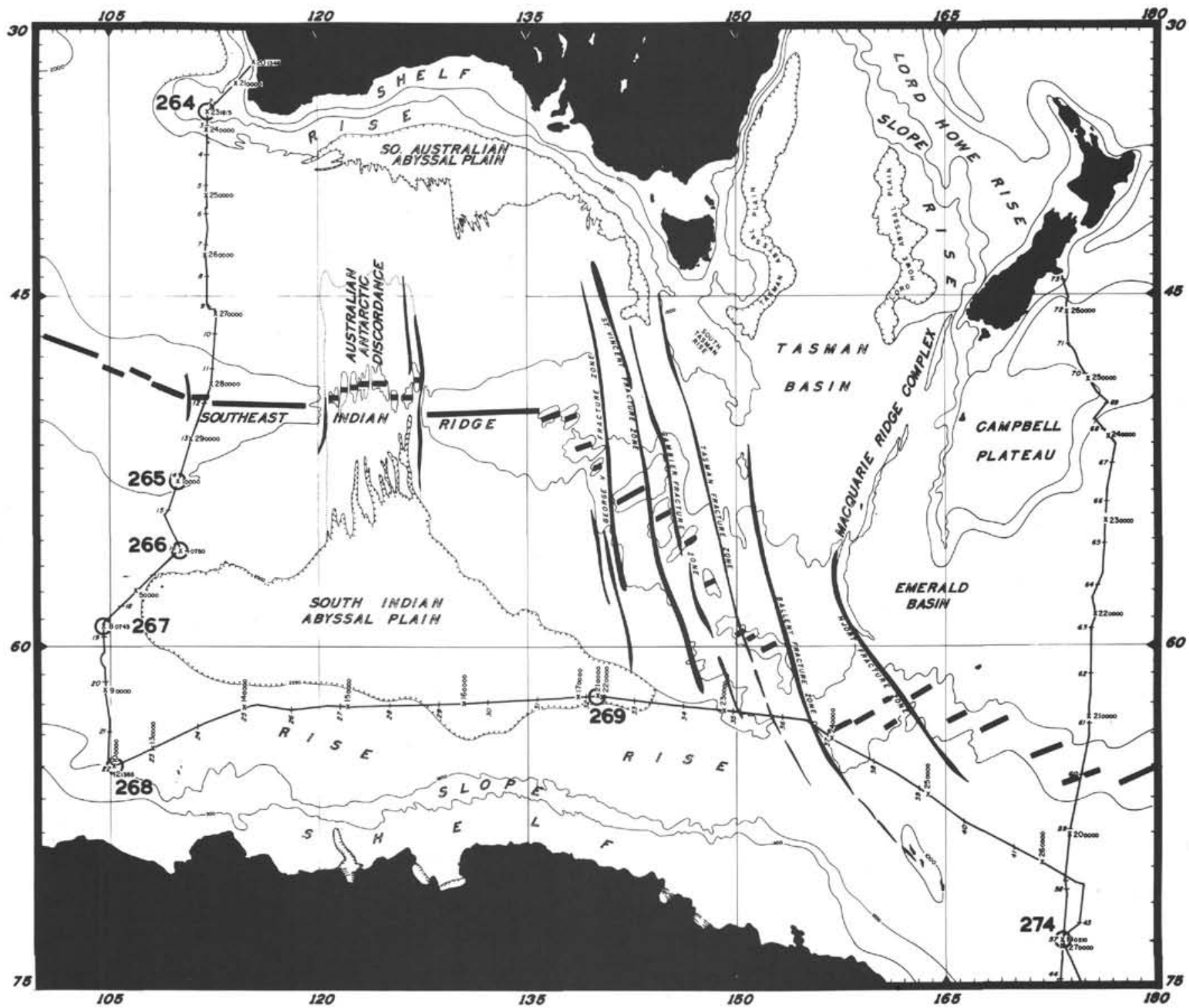

Figure 1b. (Continued).

the Ross continental shelf, the reader is referred to Hayes and Davey (this volume).

The Ross Continental Shelf was traversed from mile 4500 through mile 5400 . The general depth of the shelf is two to three times that of normal continental shelves throughout the world. The relief on the shelf is thought to be primarily the result of glacial erosion by a previously more extensive grounded ice shelf (Hayes and Davey, this volume; Hayes and Frakes, this volume). Although the multiple reflections obscure the deep structure of the Ross Continental Shelf, the disposition of the sedimentary horizons can be seen clearly in several locations and in many places the layers dip gently and have been truncated at or near the sea surface (see also Houtz and Davey, 1973), for example, near mile 4650 and miles 4900 to 5200 . The significance of these truncations is discussed in detail in the combined site chapter for Sites 270,271 , and 272, and also for the site chapter 273 and in the synthesis chapter (Hayes and Frakes, this volume).
Upon departing Site 274 for the long 2000-mile transit to New Zealand, the ship first crossed that portion of the Antarctic plate associated with sea-floor spreading between Australia and Antarctica, but later, near mile 5850 , crossed that portion of the Antarctic plate associated with spreading between the Antarctic and the Pacific plates. The Pacific-Antarctic Ridge in this region is very highly fractured; typical ridge and valley relief is on the order of 500 fathoms. The magnetic anomaly pattern associated with the crestal portion of the PacificAntarctic Ridge is not clear. However, the magnetic anomalies older than anomaly 25 are well developed and are labeled on the geophysics profile between about miles 6200 and 6800 . The quality of the profile records is again poor in the sub-Antarctic region transiting the Antarctic Convergence. The record quality improved near mile 6450 and was good for the remainder of the cruise. The sediment disposition for the portion of the Pacific plate lying between miles 6500 and 6850 is typical of that shown by others (see, for example, Hayes et al., 


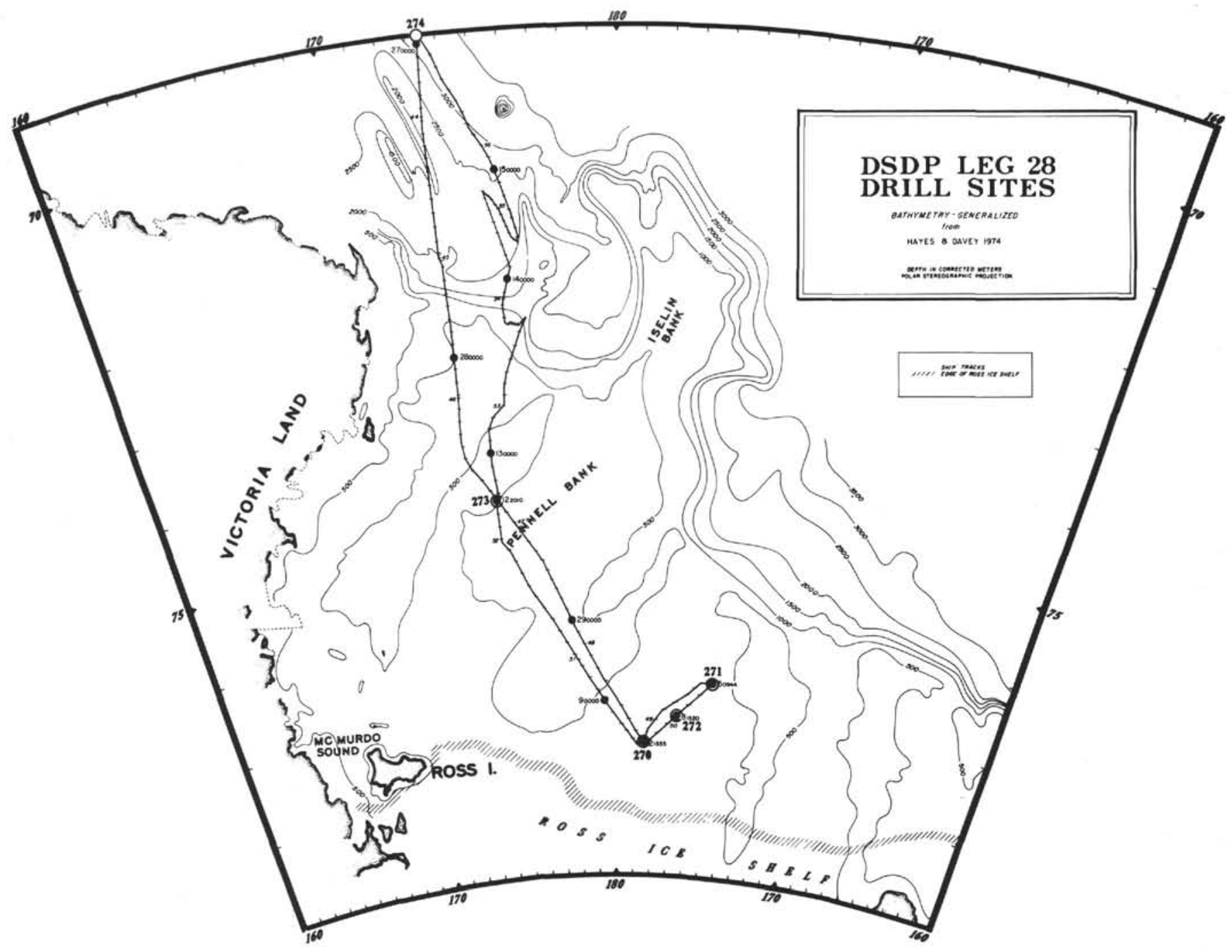

Figure 1c. (Continued).

1972; Houtz et al., 1973). From about mile 6900 to mile $7100,50-300$ meters of sediment can be seen in various places on the Campbell Plateau. The incised canyon systems running through the fairly well-mapped Bounty Trough are evident at miles 7170 and 7220 .

The general crustal evolution and the history of seafloor spreading for the region lying south of the Campbell Plateau has been discussed by Hayes and Ringis (1973), Christoffel and Falconer (1972), and Molnar et al. (in press).

\section{ACKNOWLEDGMENTS}

The fine efforts of the Deep Sea Drilling Project technical staff in the collection of the Leg 28 geophysical data are gratefully acknowledged. The technical staff was under the direction of R. Illucci, party chief. I thank R. Shearer for her assistance in the computer reduction of the data and Jeff Weissel for reviewing the magnetic lineations identifications shown on the geophysical profiles.

\section{REFERENCES}

Cain, J.C., Henricks, S., Daniels, W.E., and Jensen, J.C., 1968. Computation of the main geomagnetic field from spherical harmonic expansions: Data User's Note NSSDC68-11, Greenbelt, Md.

Christoffel, D.A. and Falconer, R.K.H., 1972. Marine magnetics measurements in the Southwest Pacific Ocean. In Hayes, D.E. (Ed.), Antarctic Oceanology II: the Australian-New Zealand Sector, Antarctic Res. Ser., v: 19: Washington (Am. Geophys. Union), p. 165-196.

Hayes, D.E. and Conolly, J.R., 1972. Morphology of the Southeast Indian Ocean. In Hayes, D.E. (Ed.), Antarctic Oceanology II: The Australian-New Zealand Sector, Antarctic Res. Ser., v. 19: Washington (Am. Geophys. Union), p. 125-146.

Hayes, D.E. and Ringis, J., 1973. Sea floor spreading in the Tasman Sea: Nature, v. 243, p. 454-458.

Hayes, D.E., Talwani, M., Houtz, R., and Pitman, W.C., III, 1972. Part A: Navigation; Part B: Bathymetric, geomagnetic, and gravity profiles; Part C: Seismic reflec- 
tion profiles. In U.S.N.S. Eltanin, Cruises 28-32, March 1967-March 1968: Lamont-Doherty survey of the world ocean, v. 22: Lamont-Doherty Geological Observatory of Columbia University, Tech. Rept. No. CU-1-72.

Heezen, B., Tharp, M., and Bentley, C.R., 1972. Morphology of the earth in the Antarctic and sub-Antarctic: Antarctic Map Folio Ser., Folio 16, Am. Geographical Soc.

Heirtzler, J.R., Dickson, G.O., Herron, E.M., Pitman, W.C., III, and Le Pichon, X., 1968. Marine magnetic anomalies, geometric field reversals, and motions of the ocean floor and continents: J. Geophys. Res., v. 73, p. 2119-2136.

Houtz, R.E. and Davey, F.J., 1973. Seismic profiler and sonobuoy measurements in the Ross Sea, Antarctica: J. Geophys. Res., v. 78, p. 3448-3468.

Houtz, R., Ewing, M., Hayes, D.E., and Naini, B., 1973. Sediment isopachs in the Indian and Pacific ocean sectors $\left(105^{\circ}\right.$ to $70^{\circ} \mathrm{W}$ ): Antarctic Map Folio Ser., Folio 17, Am. Geographical Soc., p. 9-12.

Molnar, P., Atwater, T., Mammerickx, J., and Smith, S., in press. Magnetic anomalies, bathymetry and the tectonic evolution of the South Pacific since the Late Cretaceous: Roy. Astron. Soc. Geophy. J.

Talwani, M., 1969. A computer system for the reduction, storage and display of underway data acquired at sea: Lamont-Doherty Geological Observatory of Columbia University, Tech. Rept. No. 1, Cu-1-69 N00014-67-A-01080004.

Weissel, J. and Hayes, D.E., 1972. Magnetic anomalies in the Southeast Indian Ocean. In Hayes, D.E. (Ed.), Antarctic Oceanology II: the Australian-New Zealand Sector, Antarctic Res. Ser., v. 19: Washington (Am. Geophys. Union), p. 165-196. 


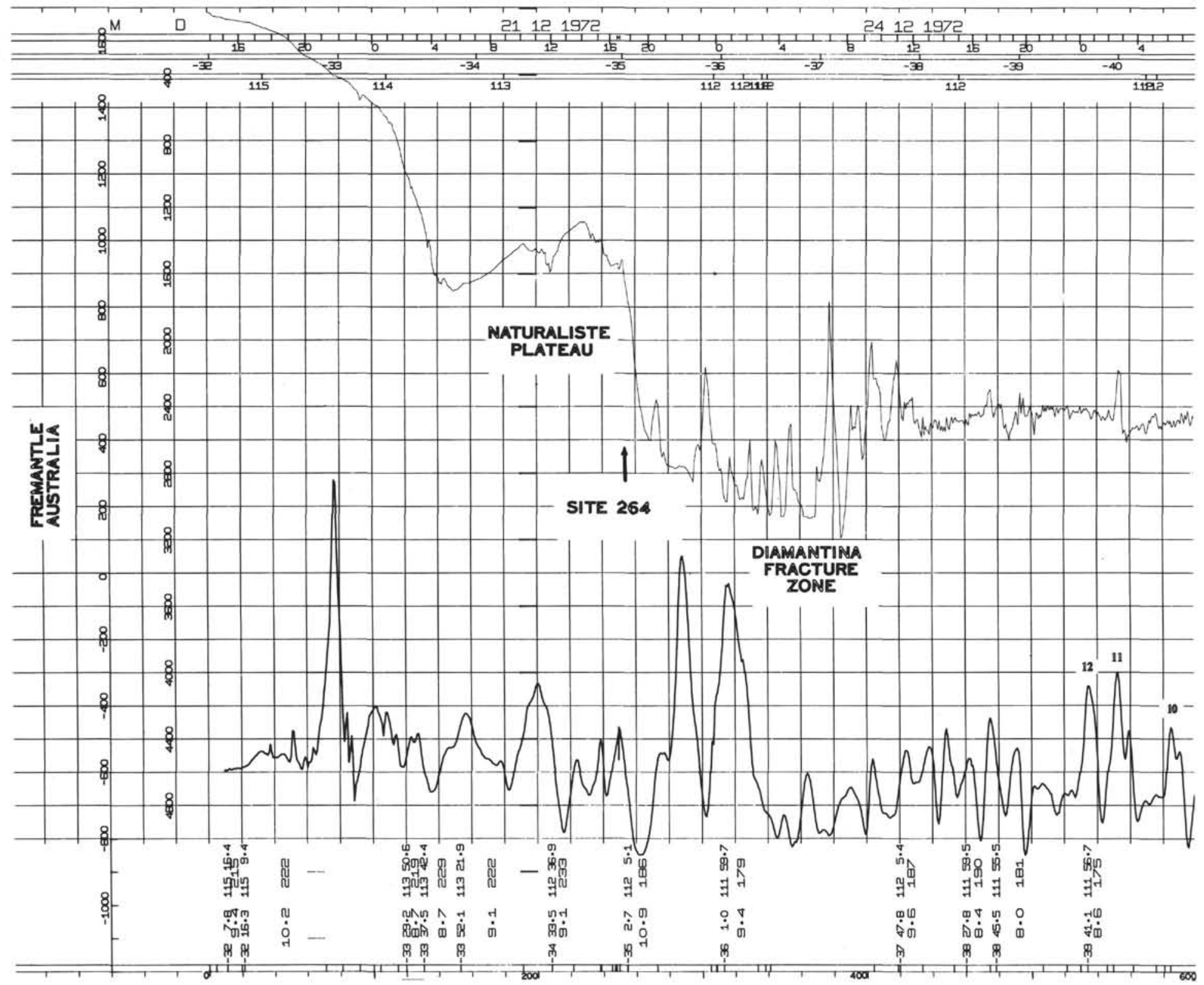

Figure 2. Reflection seismic profiles obtained by Glomar Challenger during Leg 28. Key to profile locations is given in Figure 3. 


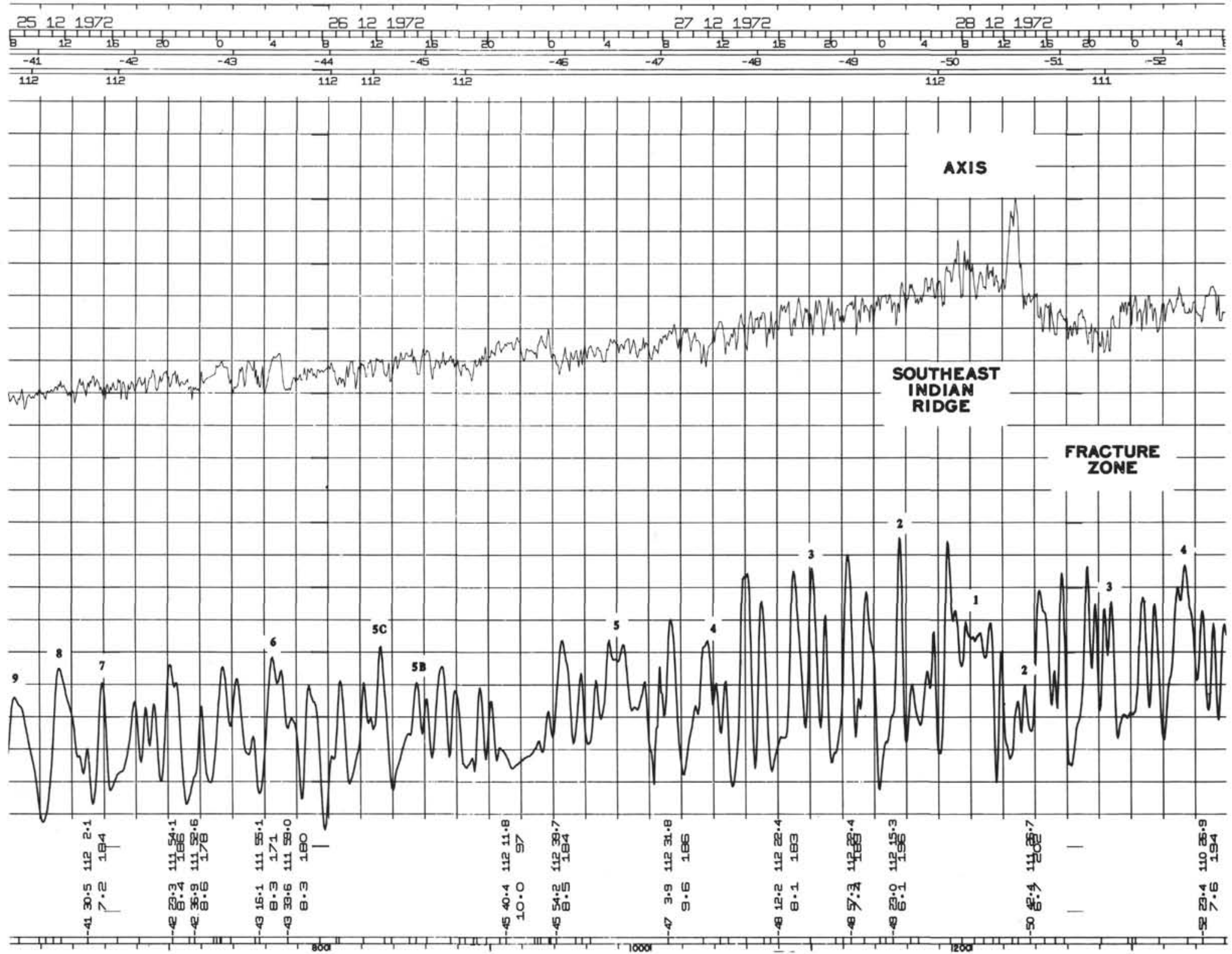

Figure 2. (Continued). 


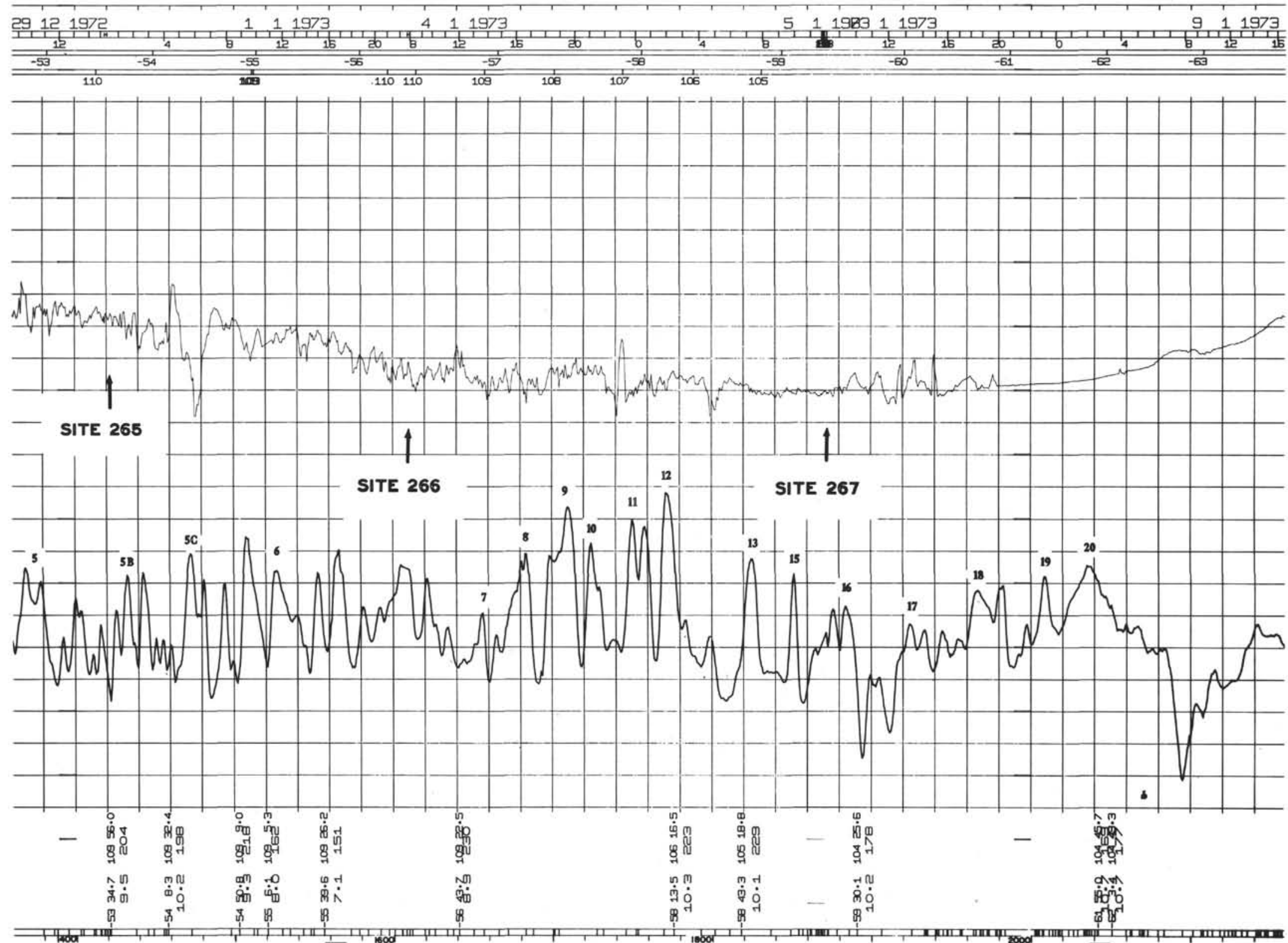

Figure 2. (Continued). 


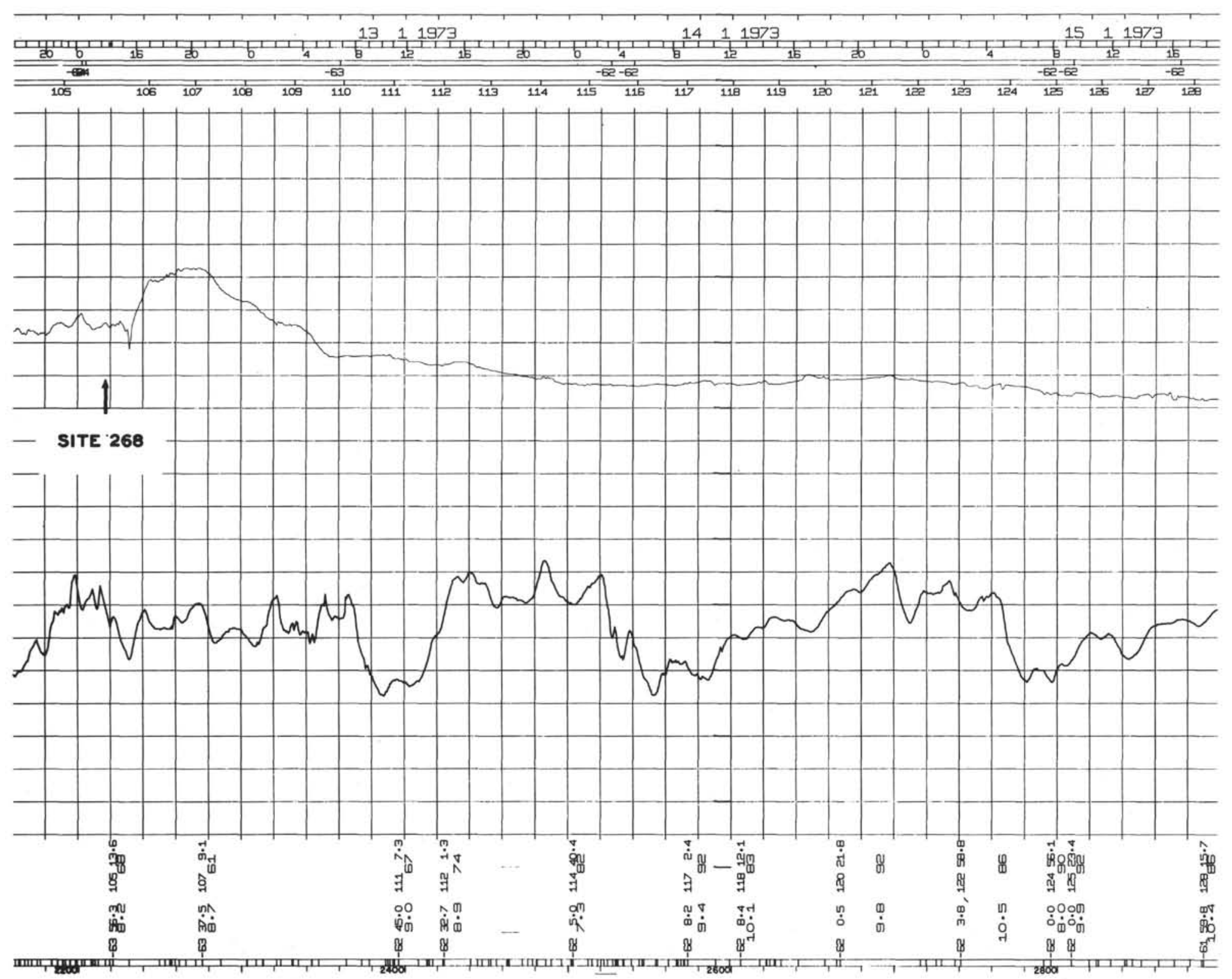

Figure 2. (Continued). 


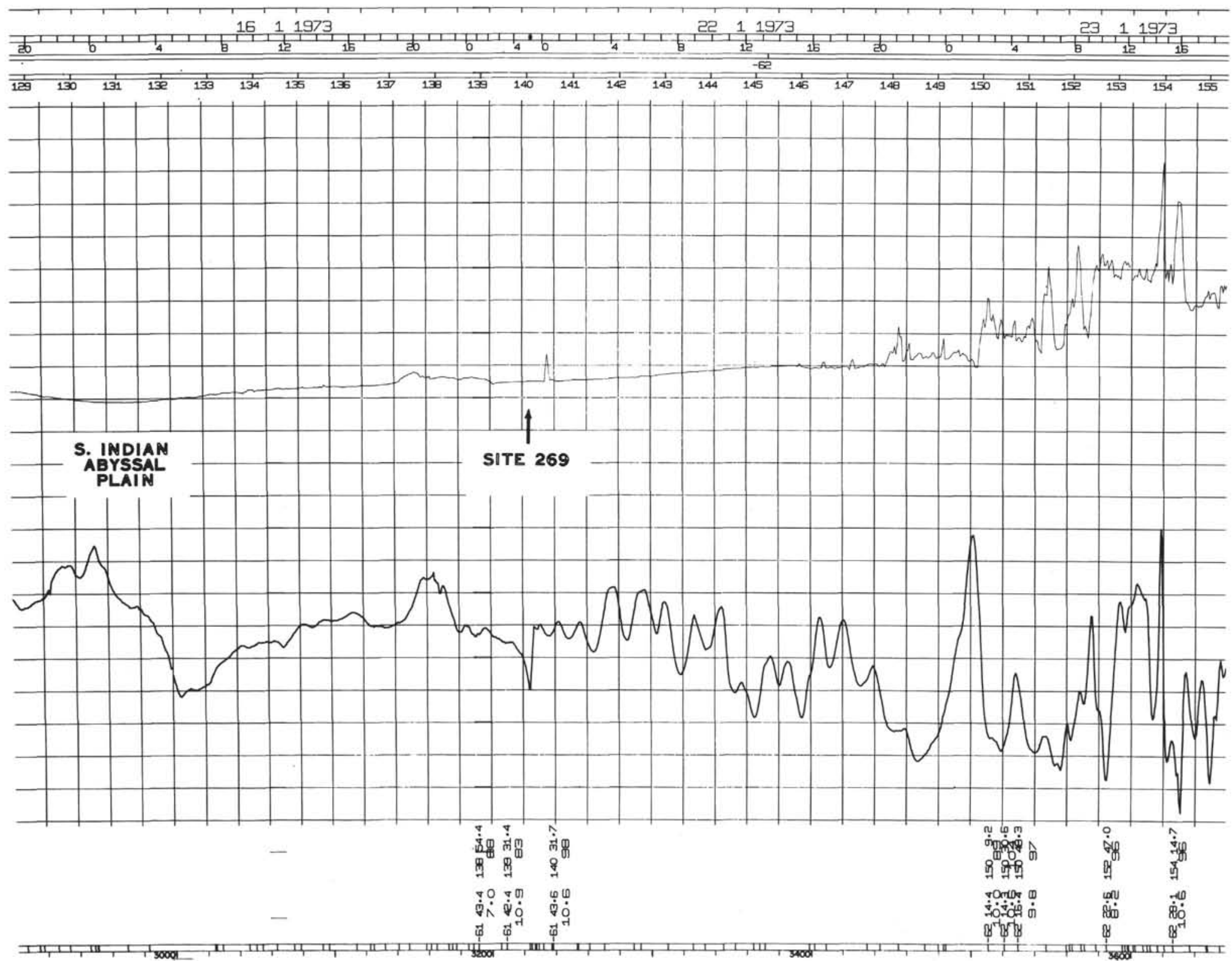

Figure 2. (Continued). 


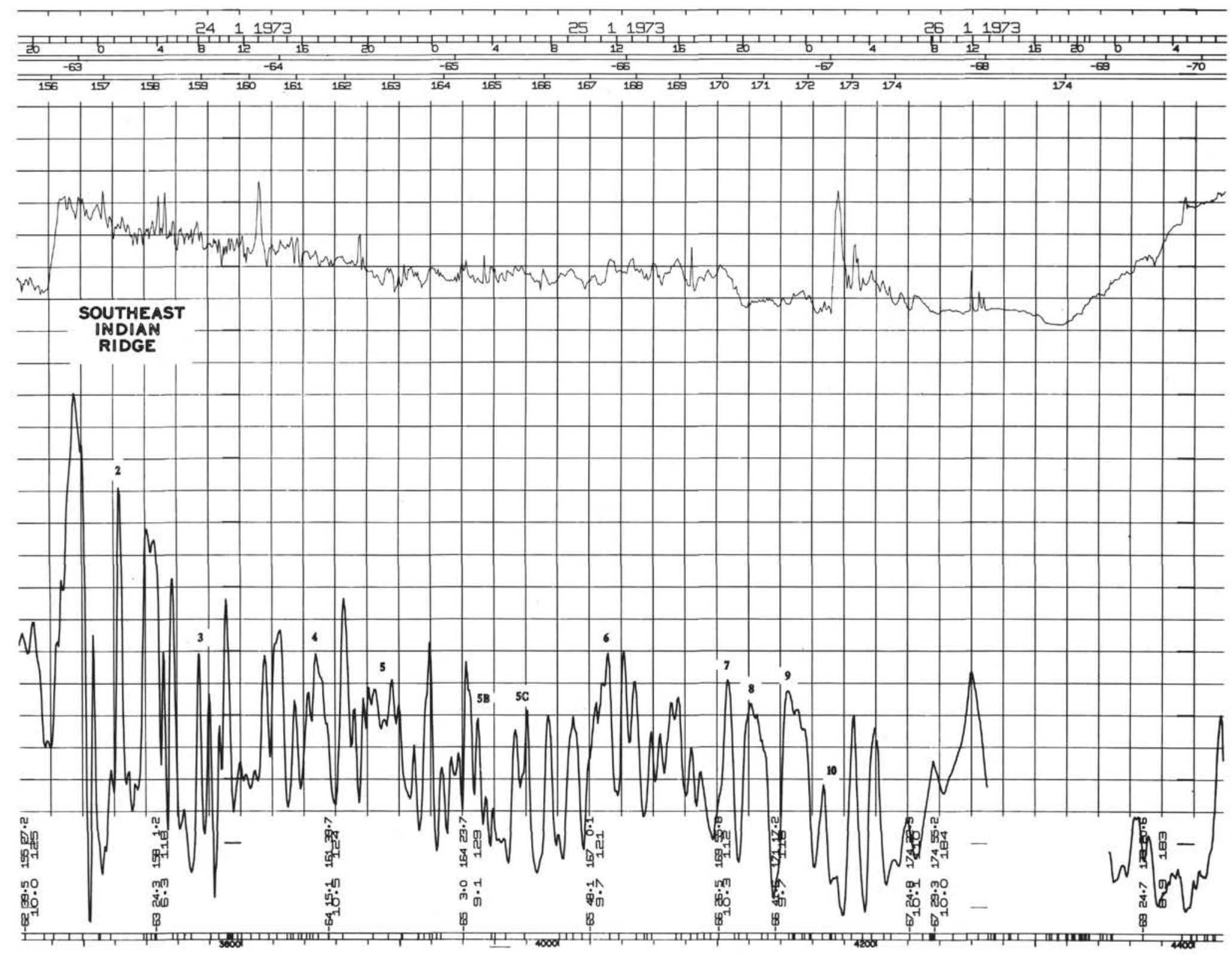

Figure 2. (Continued). 


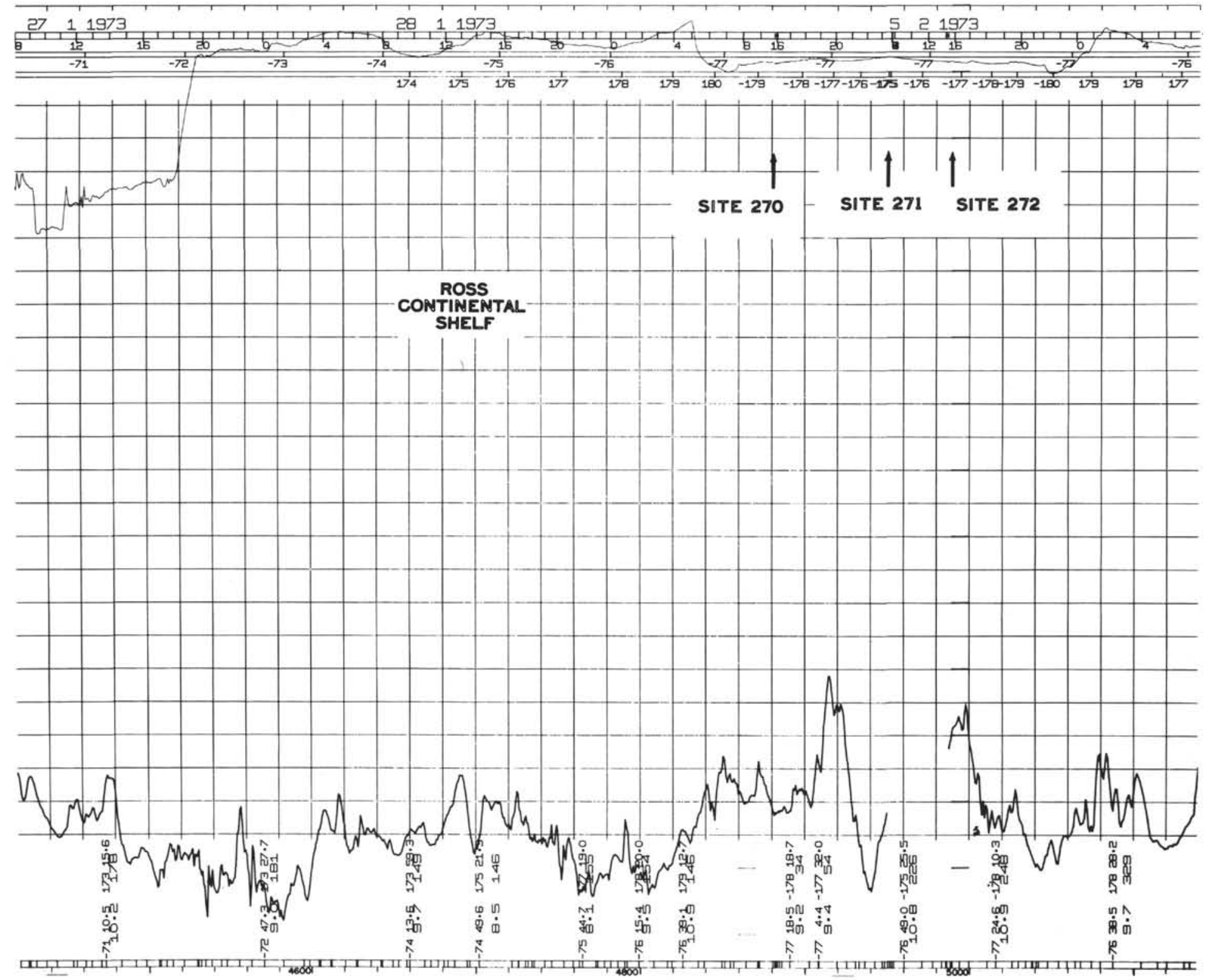

Figure 2. (Continued). 


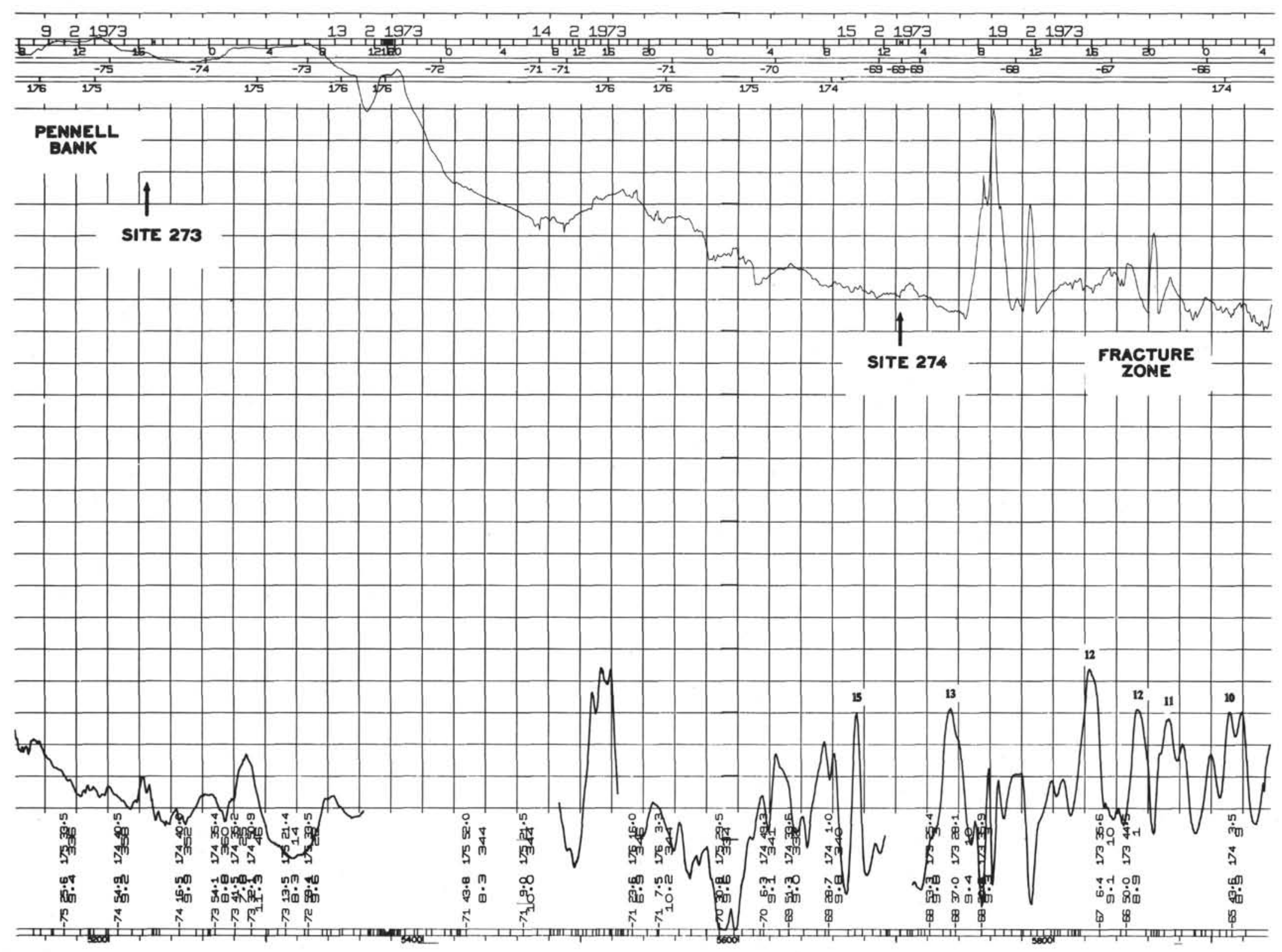

Figure 2. (Continued). 


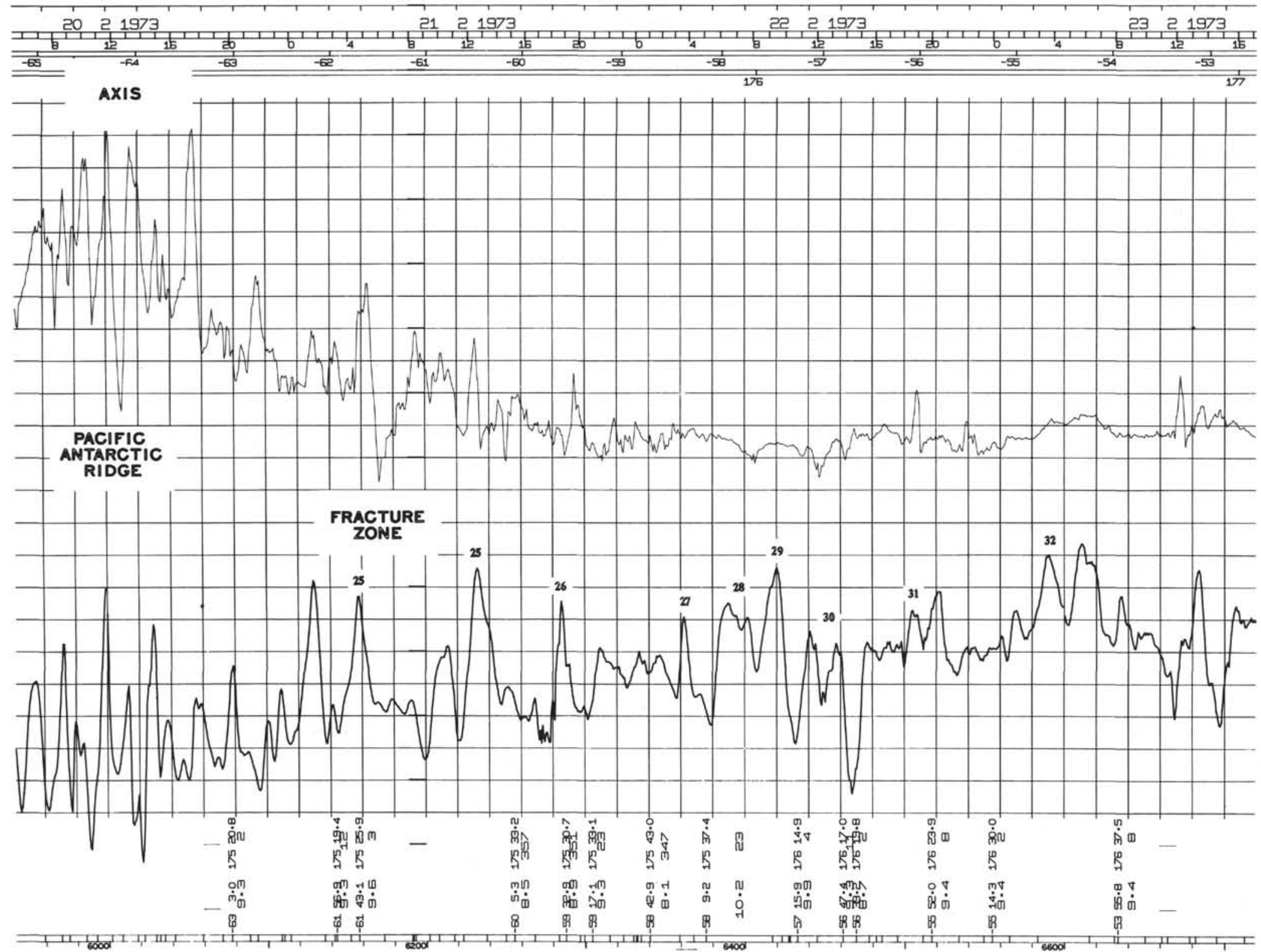

Figure 2. (Continued). 


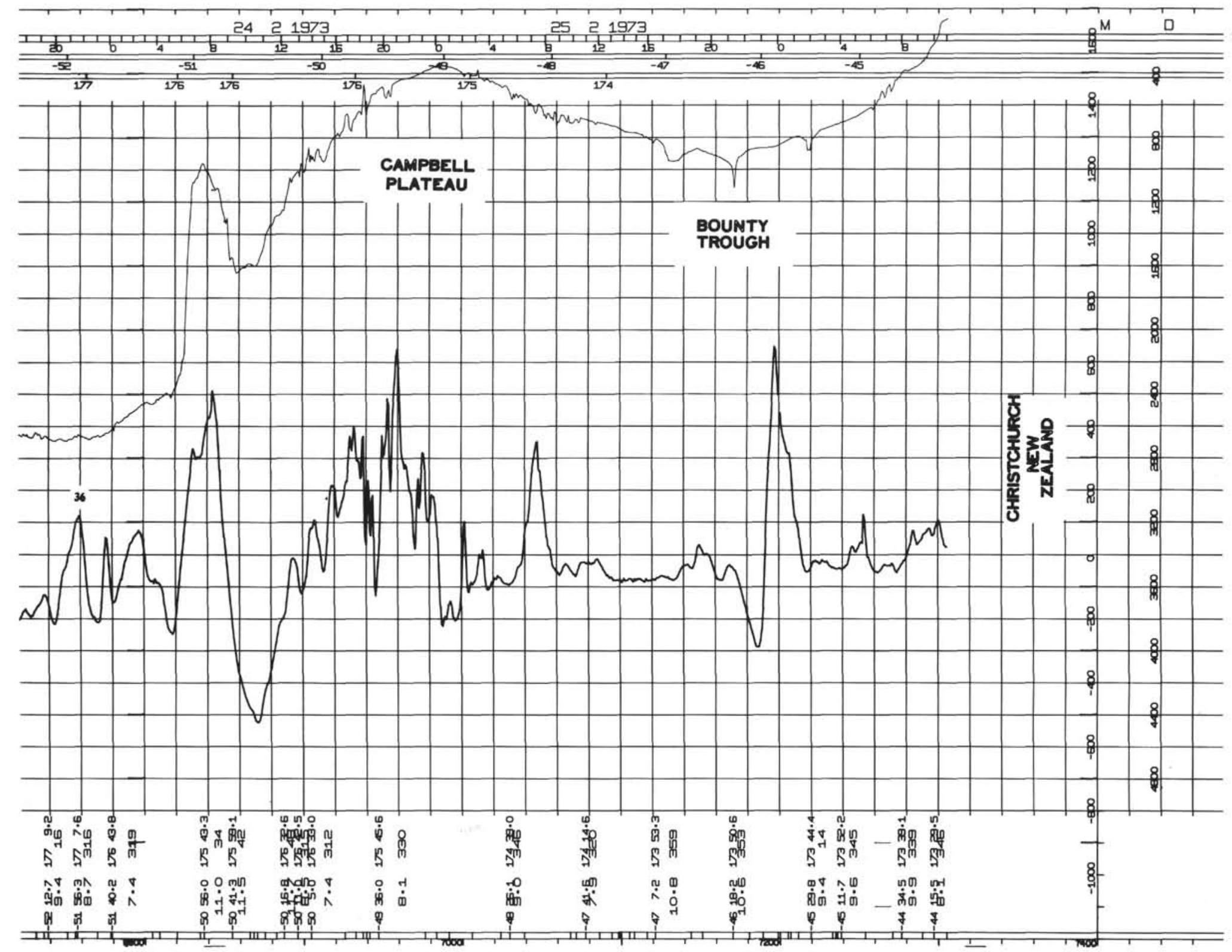

Figure 2. (Continued). 
Depart Fremantle, Aust.

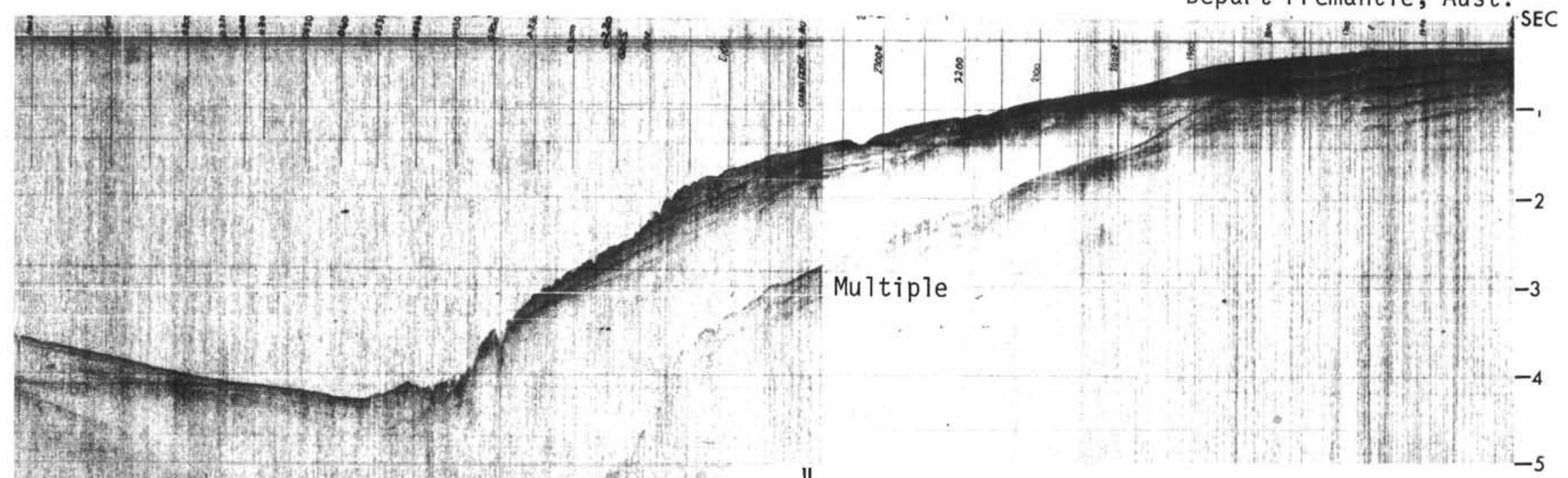
SEC

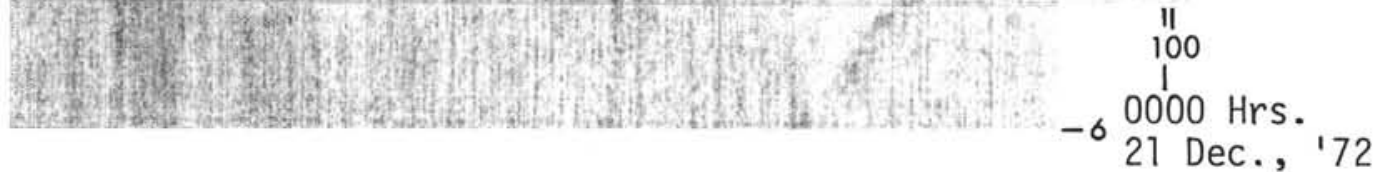

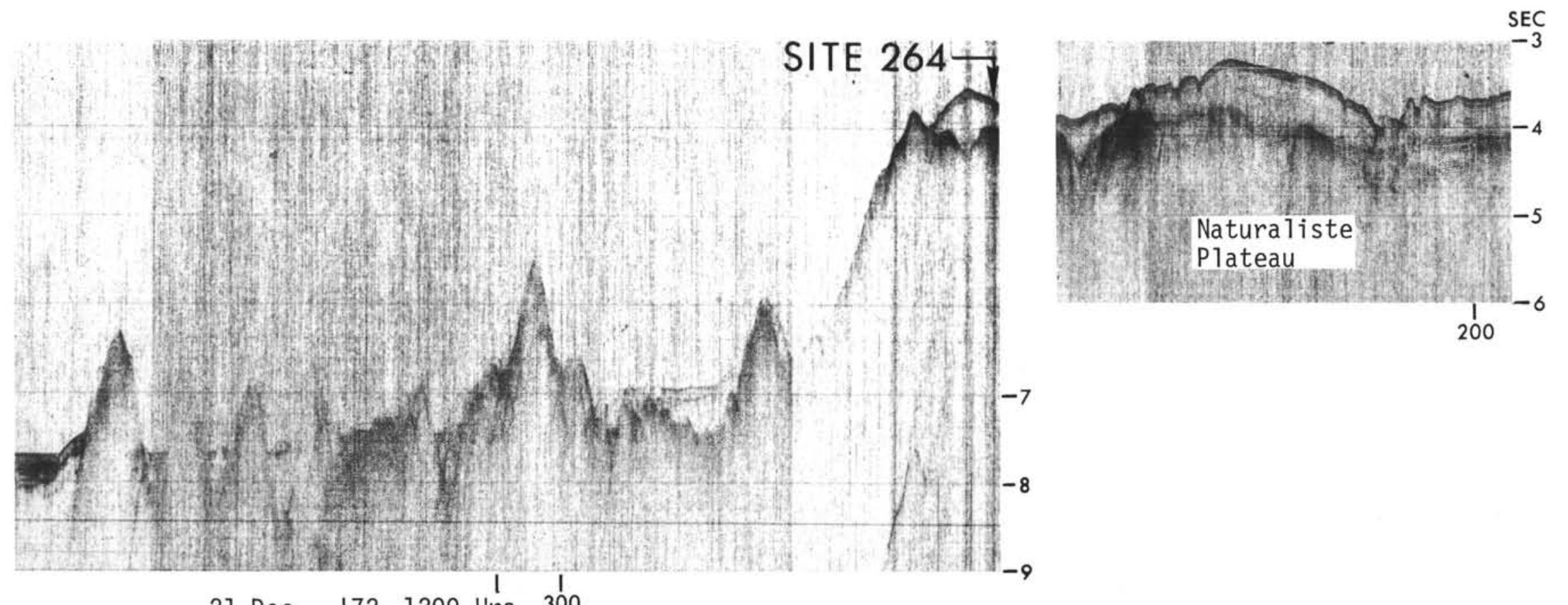

2] Dec., 1721200 Hrs. 300

Figure 3. Index map for underway geophysical data obtained by Glomar Challenger during Leg 28. The ship's track is annotated with date and time, and distance along track in hundreds of miles. 

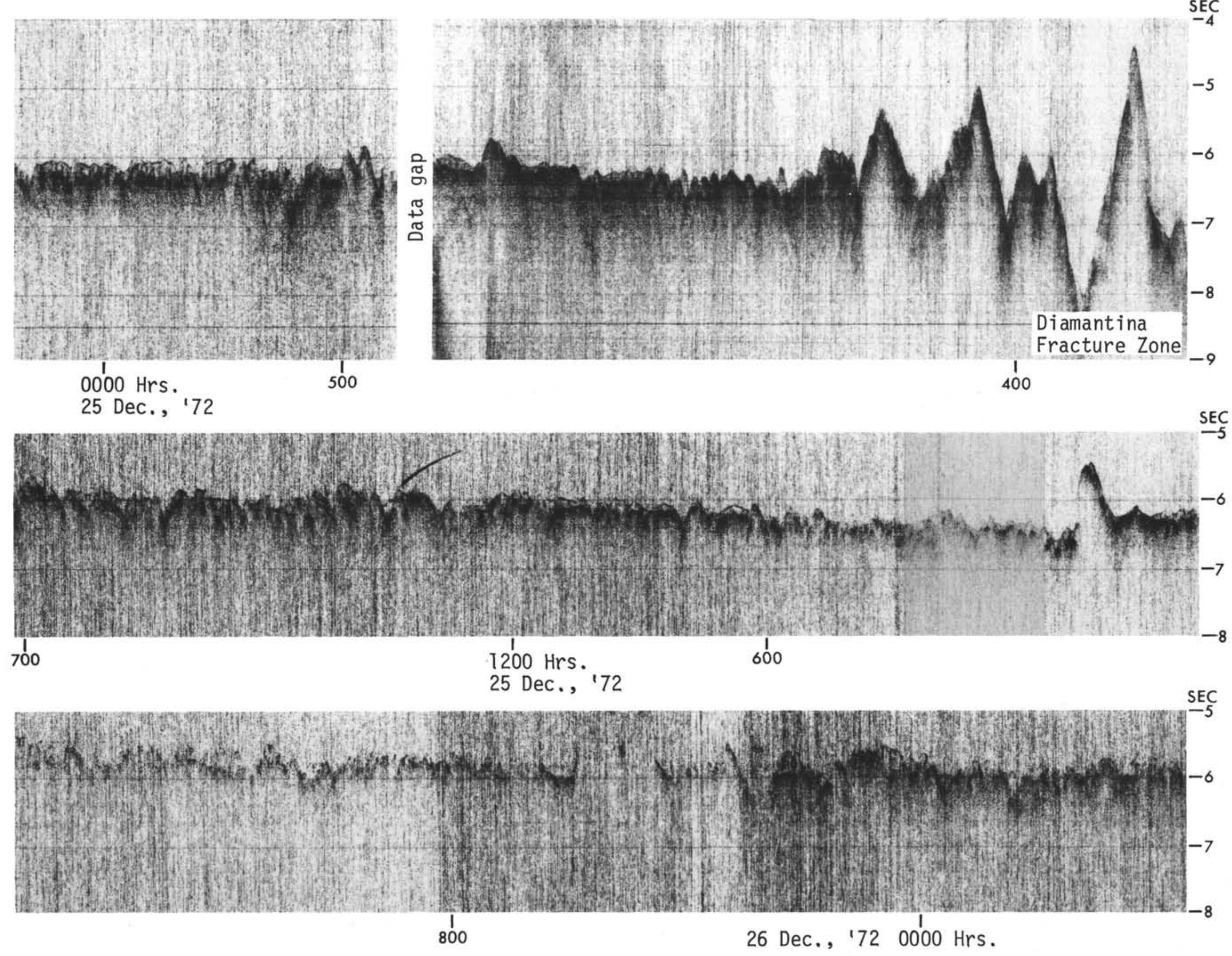

Figure 3. (Continued). 


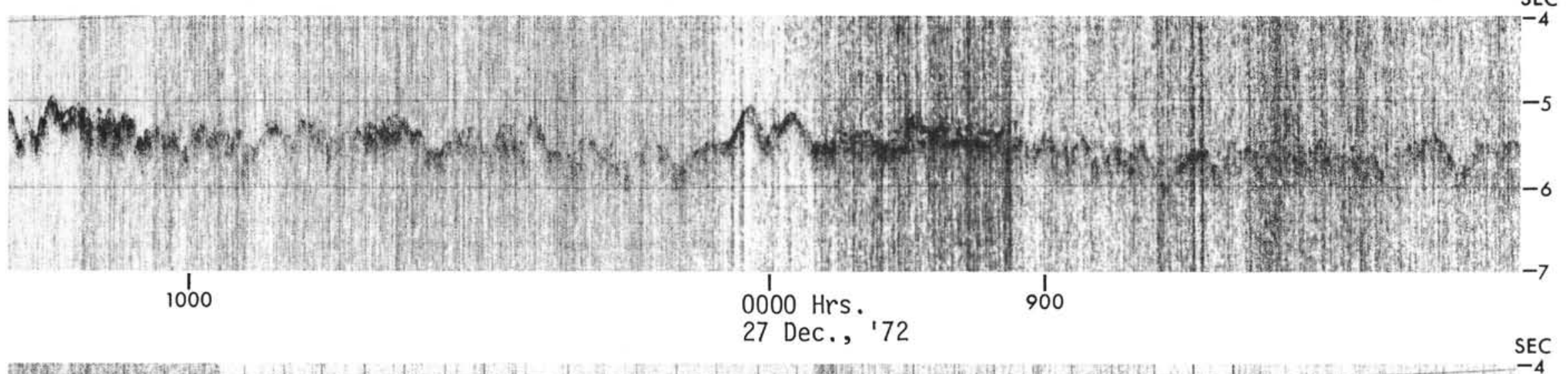

W.

0000 Hrs.

28 Dec., '72

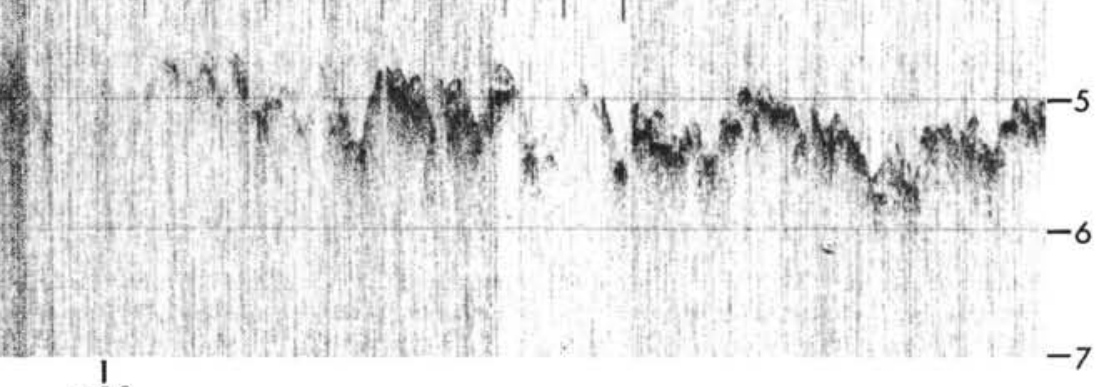
1100

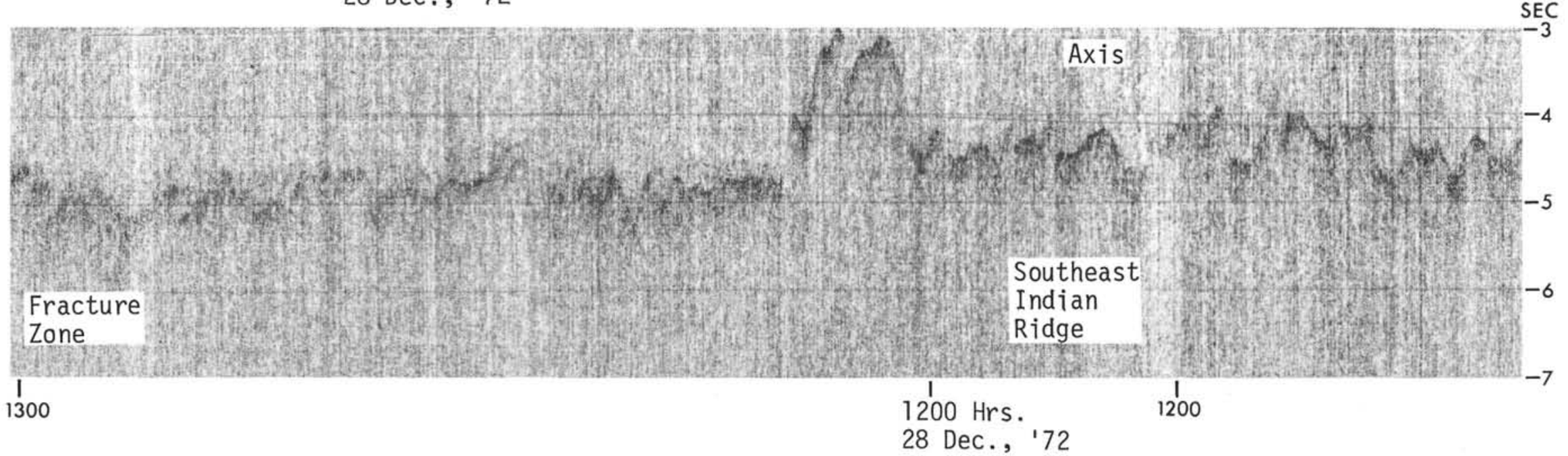

Figure 3. (Continued). 
$\mathrm{SEC}$

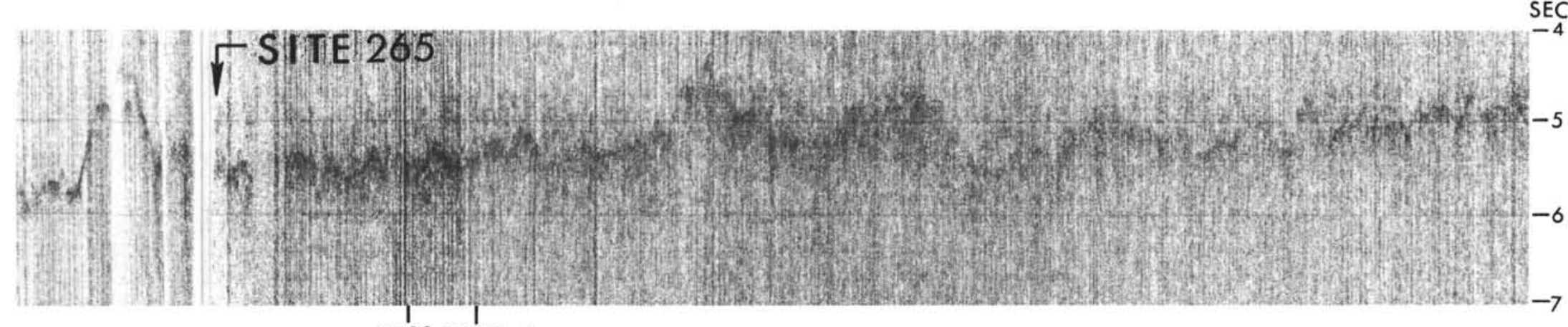

$14001200 \mathrm{Hrs}$

29 Dec., '72

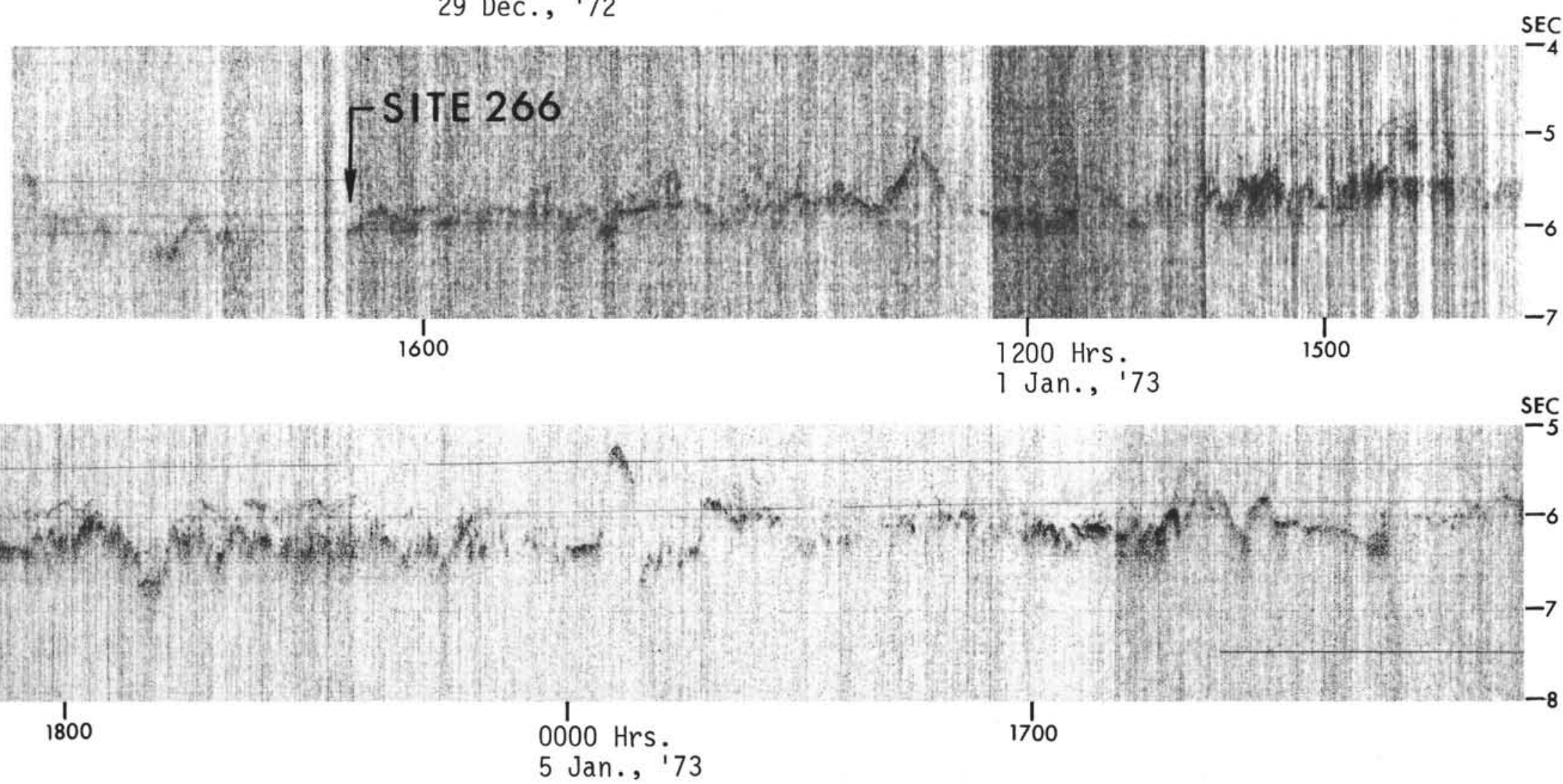

Figure 3. (Continued). 


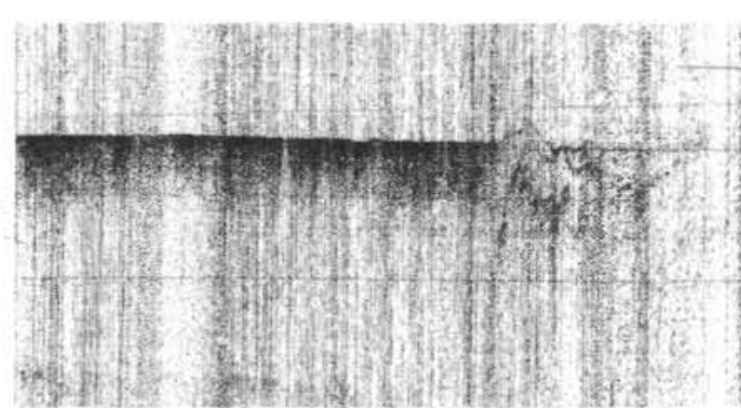
2000

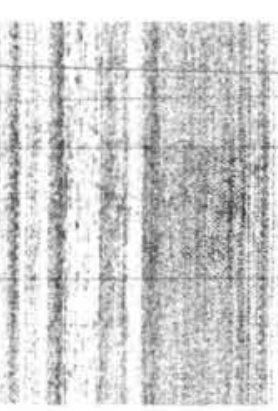

(c)

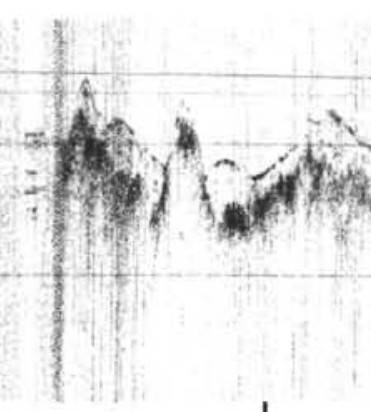

1200 Hrs 8 Jan., 73

SITE 267 -7 IIII
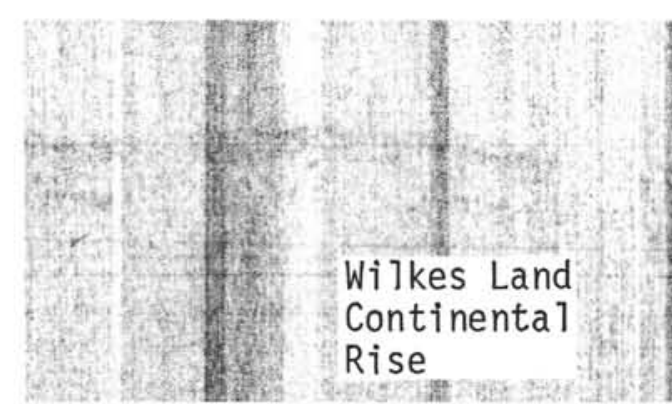

Rise

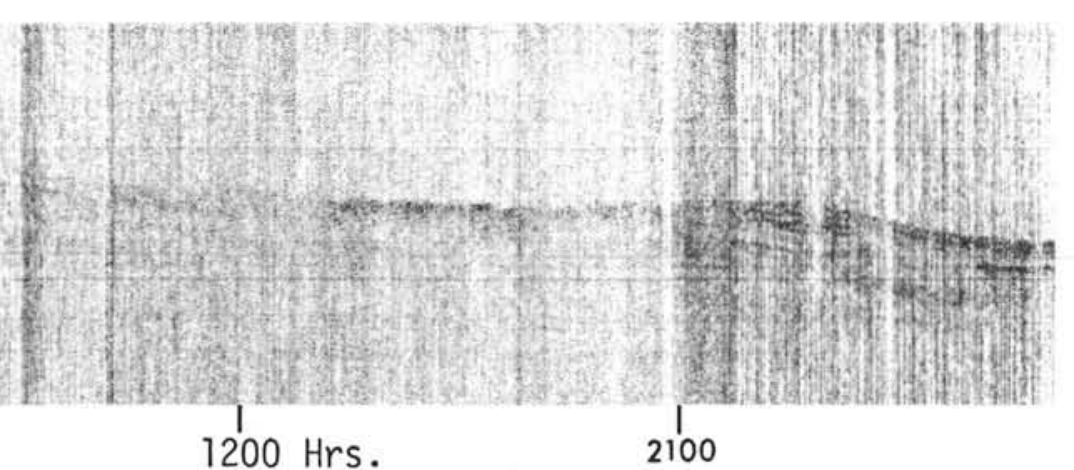

$1200 \mathrm{Hrs}$

9 Jan., '73

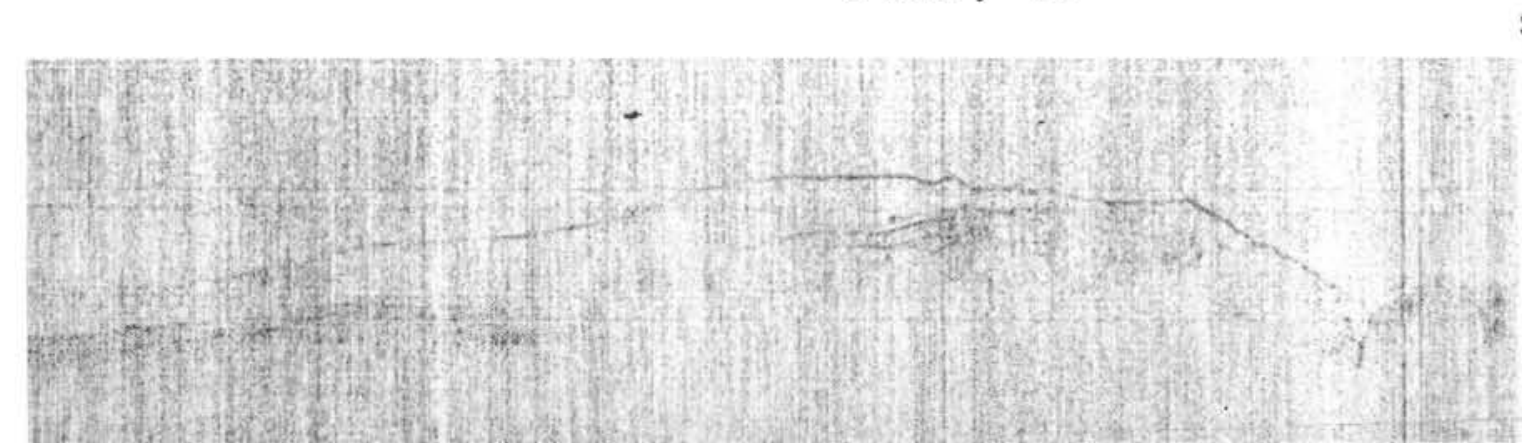
1
2300 0000 Hrs.

13 Jan., '73

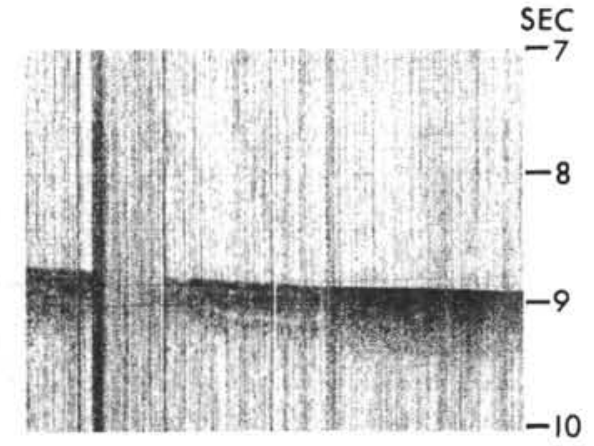

SEC
-3

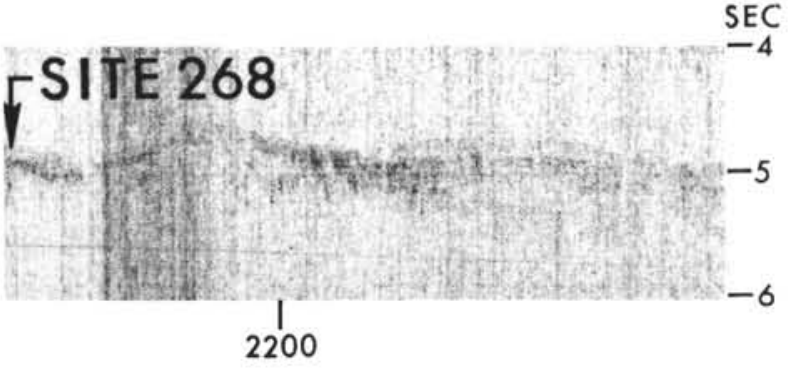

Figure 3. (Continued). 


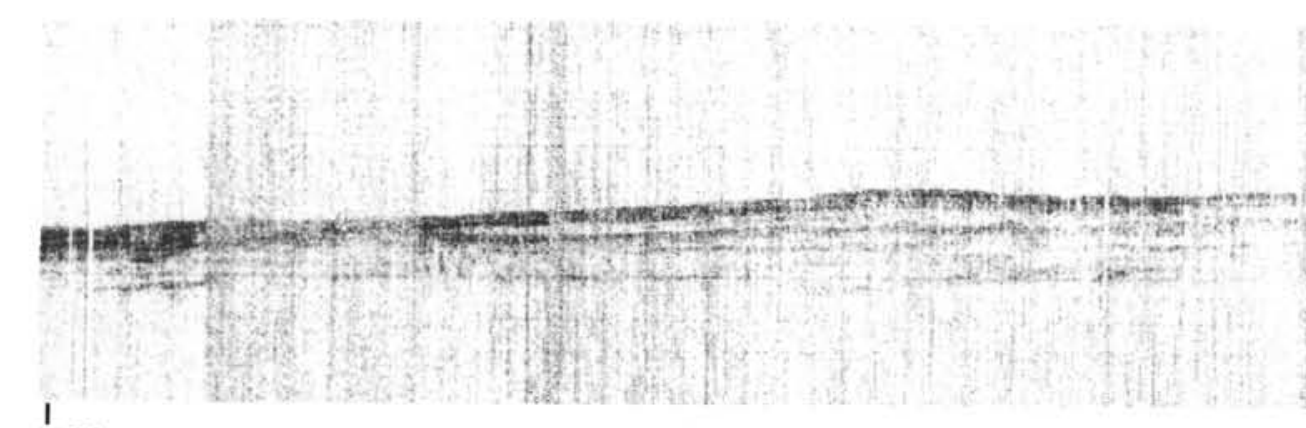
2500
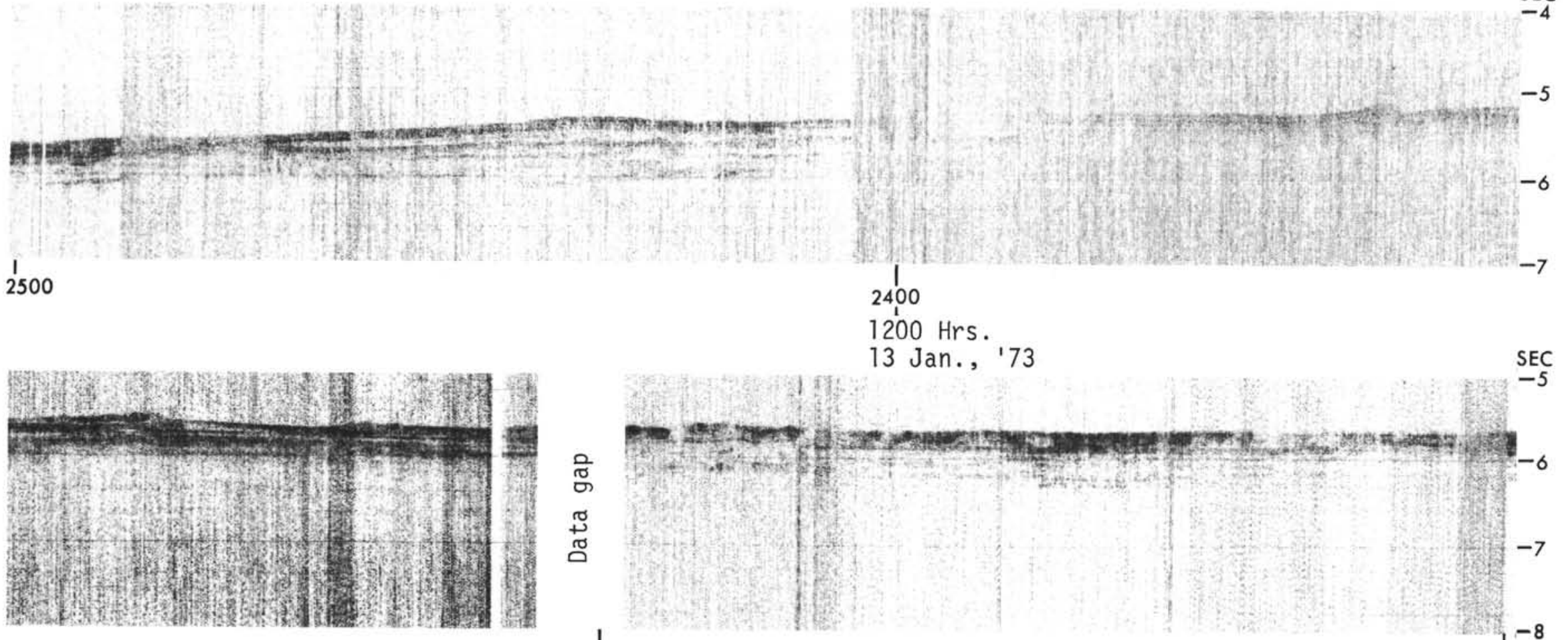

13 Jan., '73

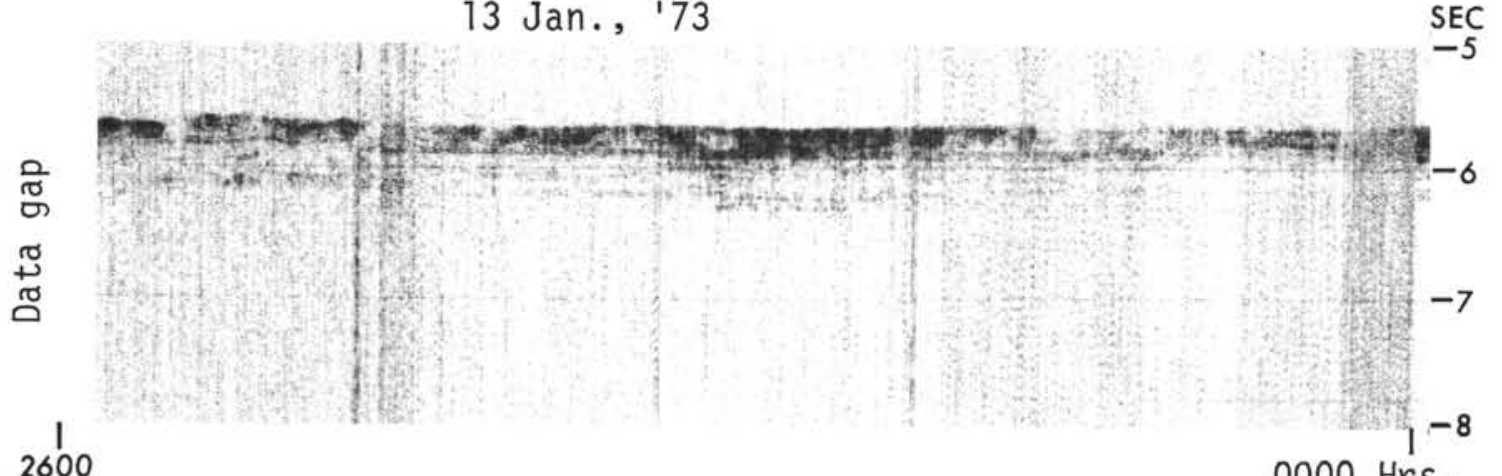

$\frac{1}{2600}$

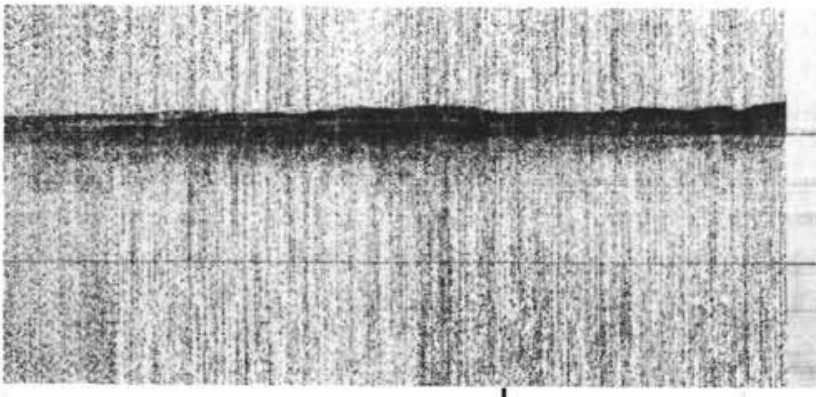
${ }_{2800}^{1}$

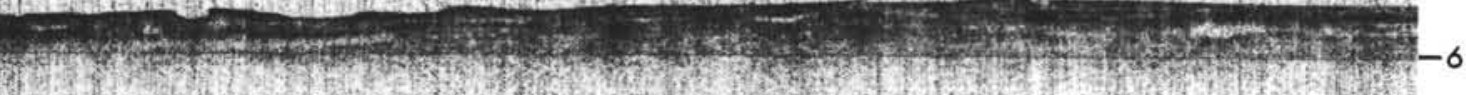

1.

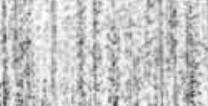

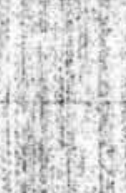

(1)

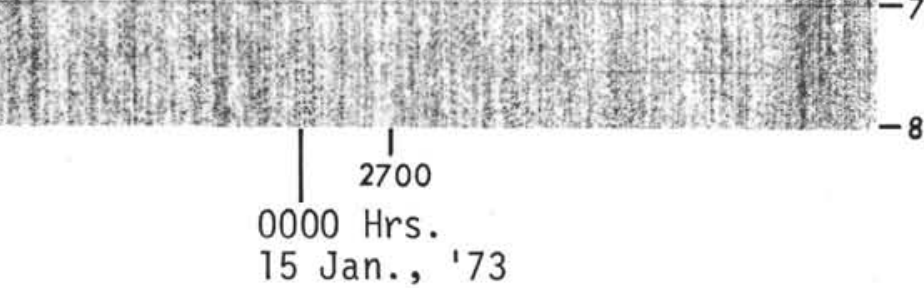

Figure 3. (Continued) 
(1) 1 (1) 3000
S. Indian

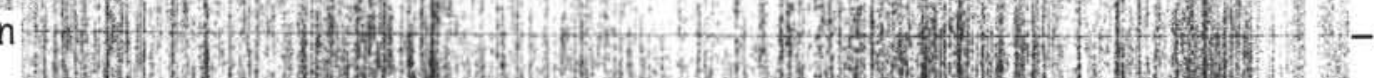
Abyssat
Plain P1ain $0000 \mathrm{Hrs}$ 16 Jan., '73 2900

SEC
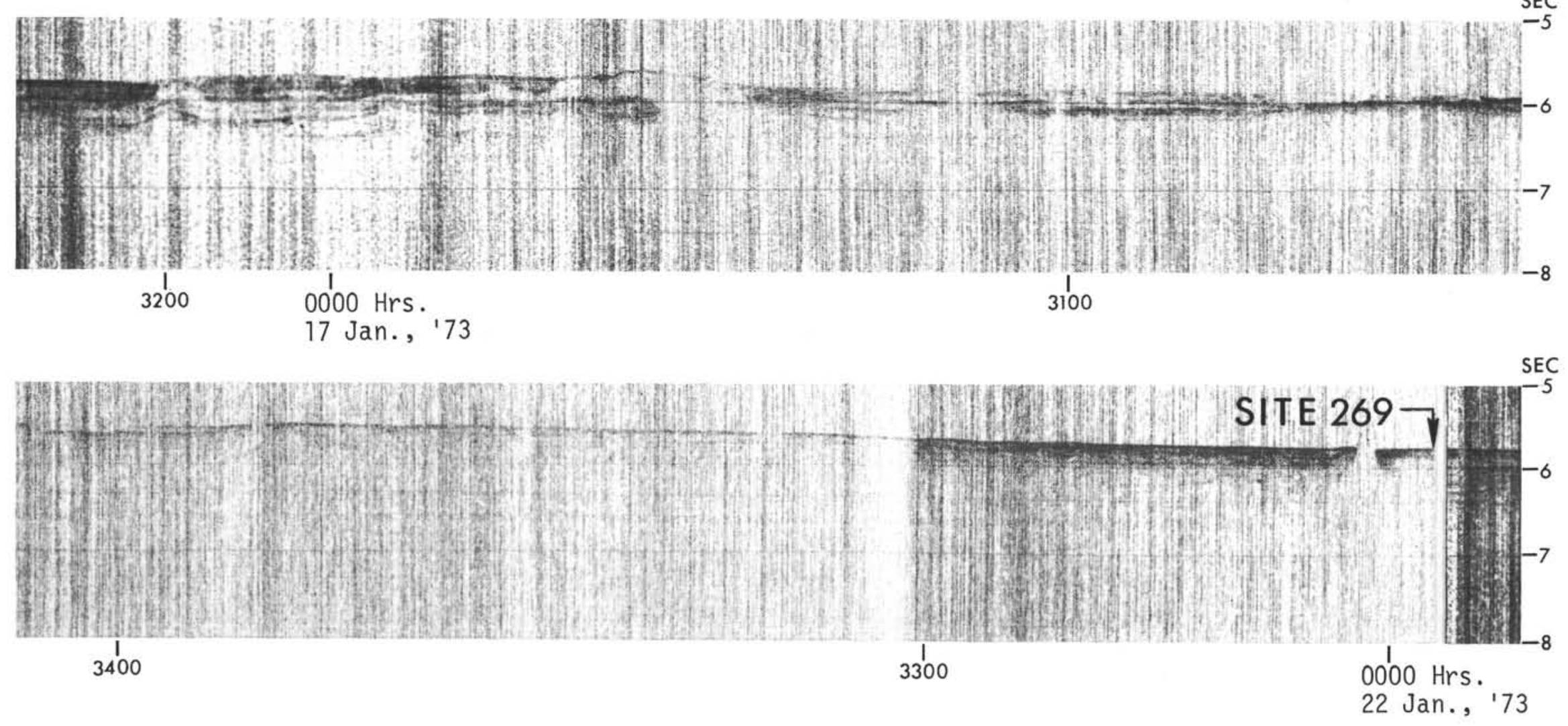

Figure 3. (Continued). 

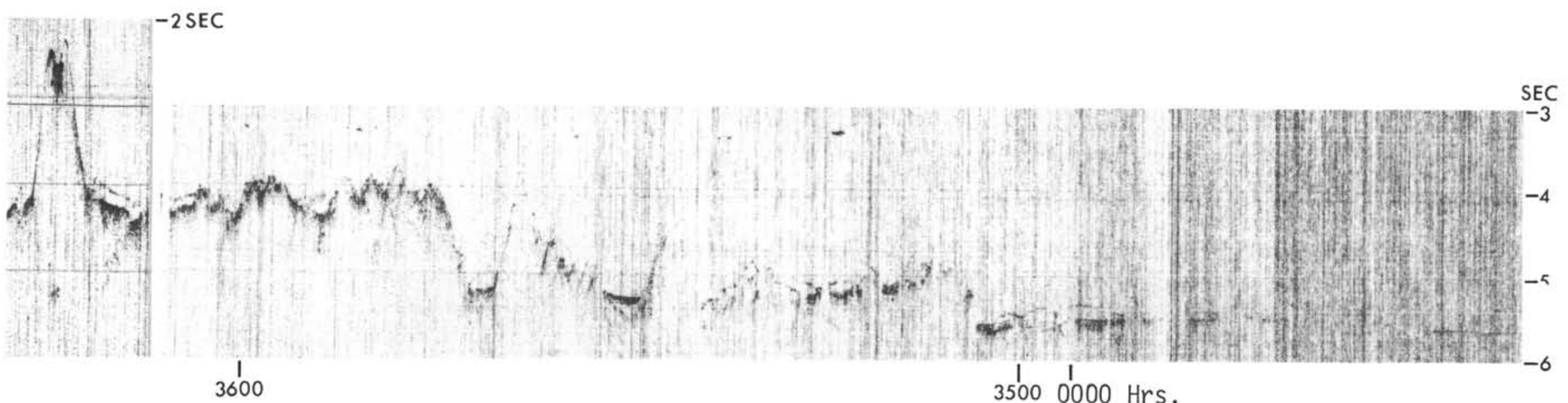
$3500 \quad 0000 \mathrm{Hrs}$

23 Jan., '73

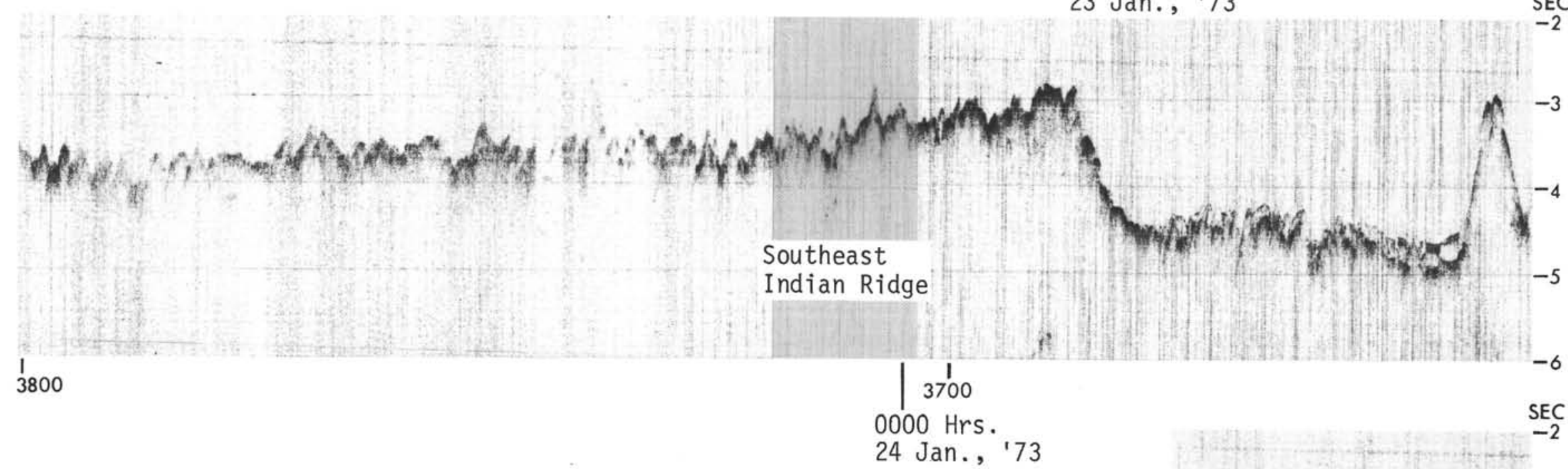

24 Jan. ' 73

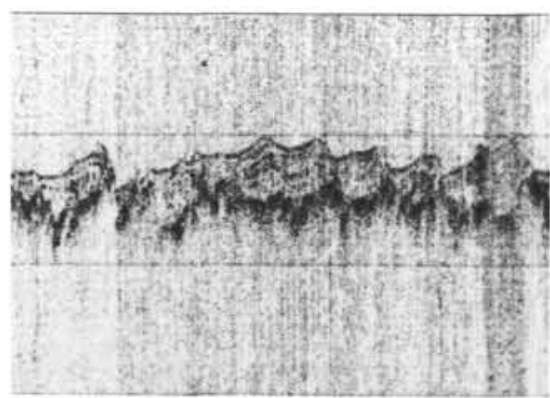

Figure 3. (Continued).

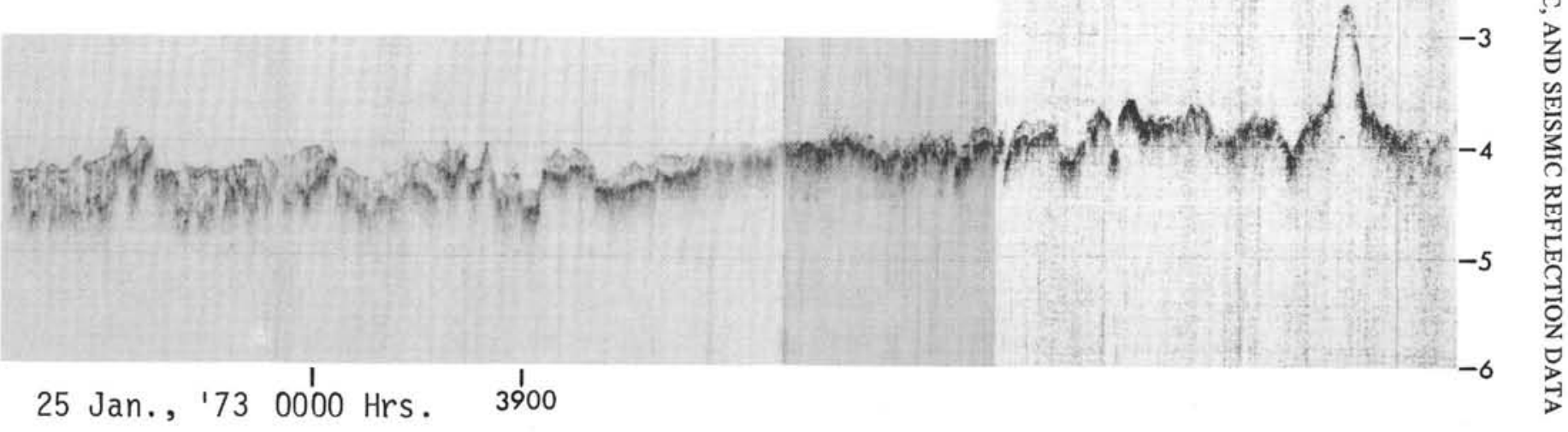



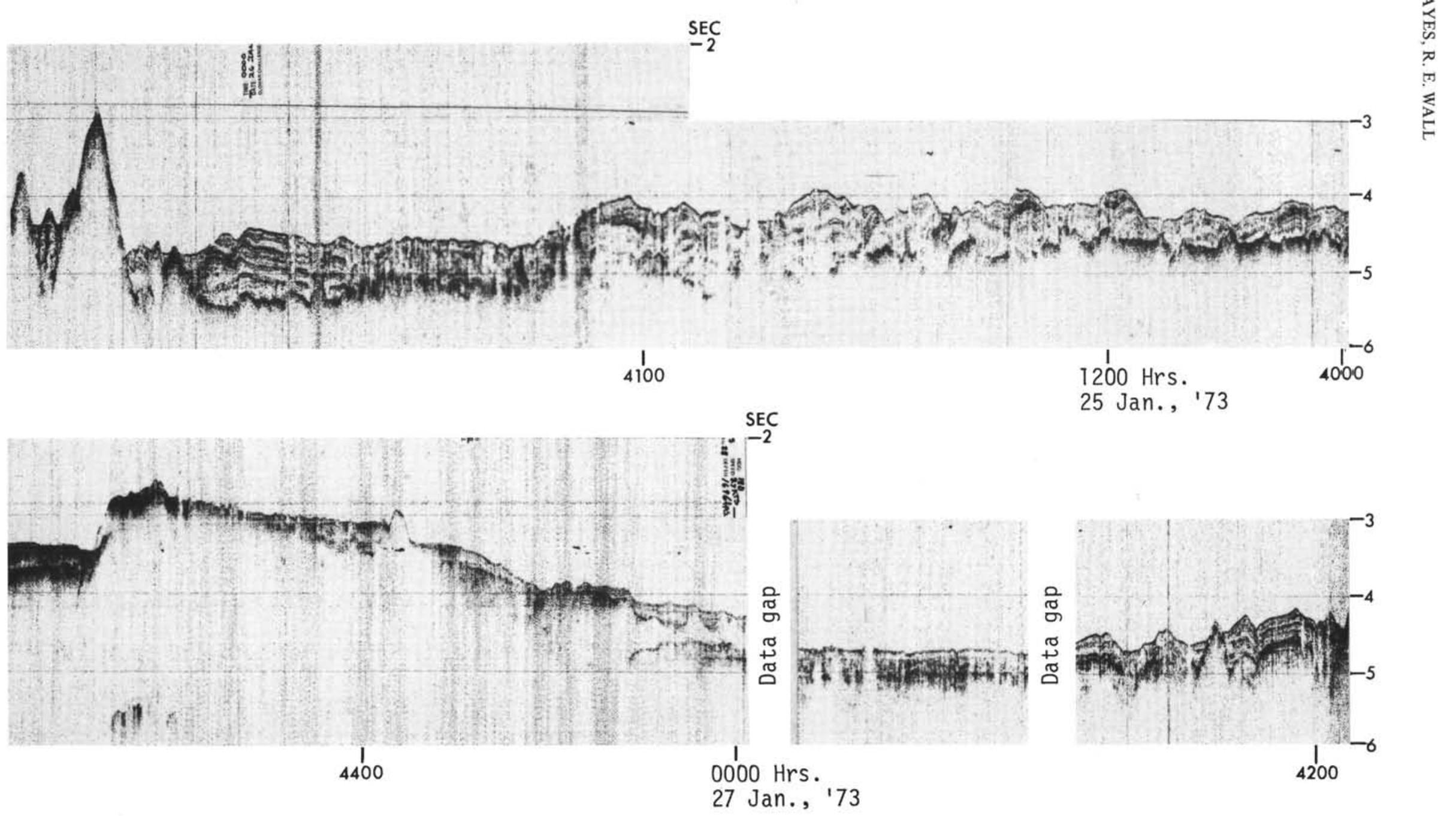

Figure 3. (Continued). 


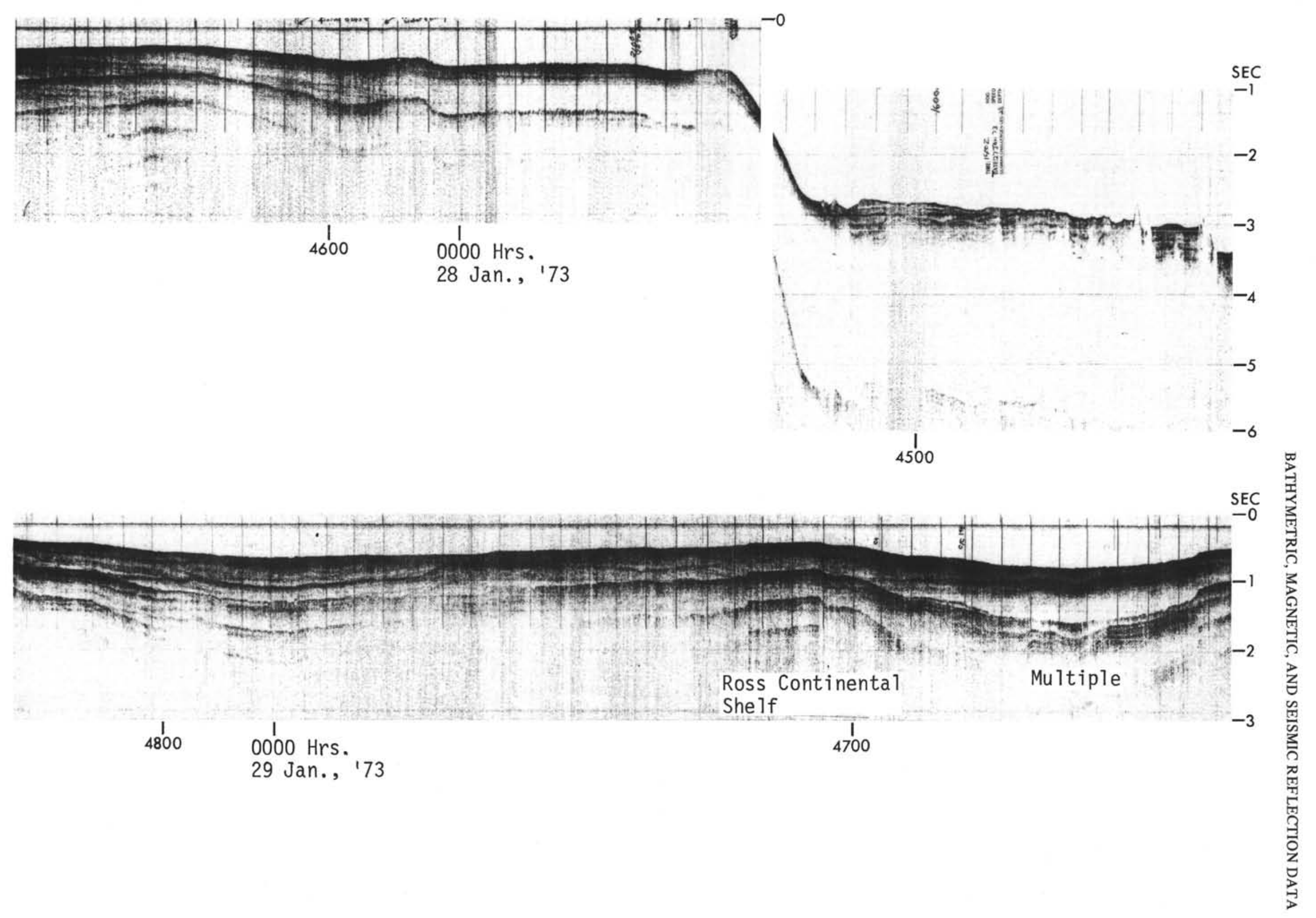




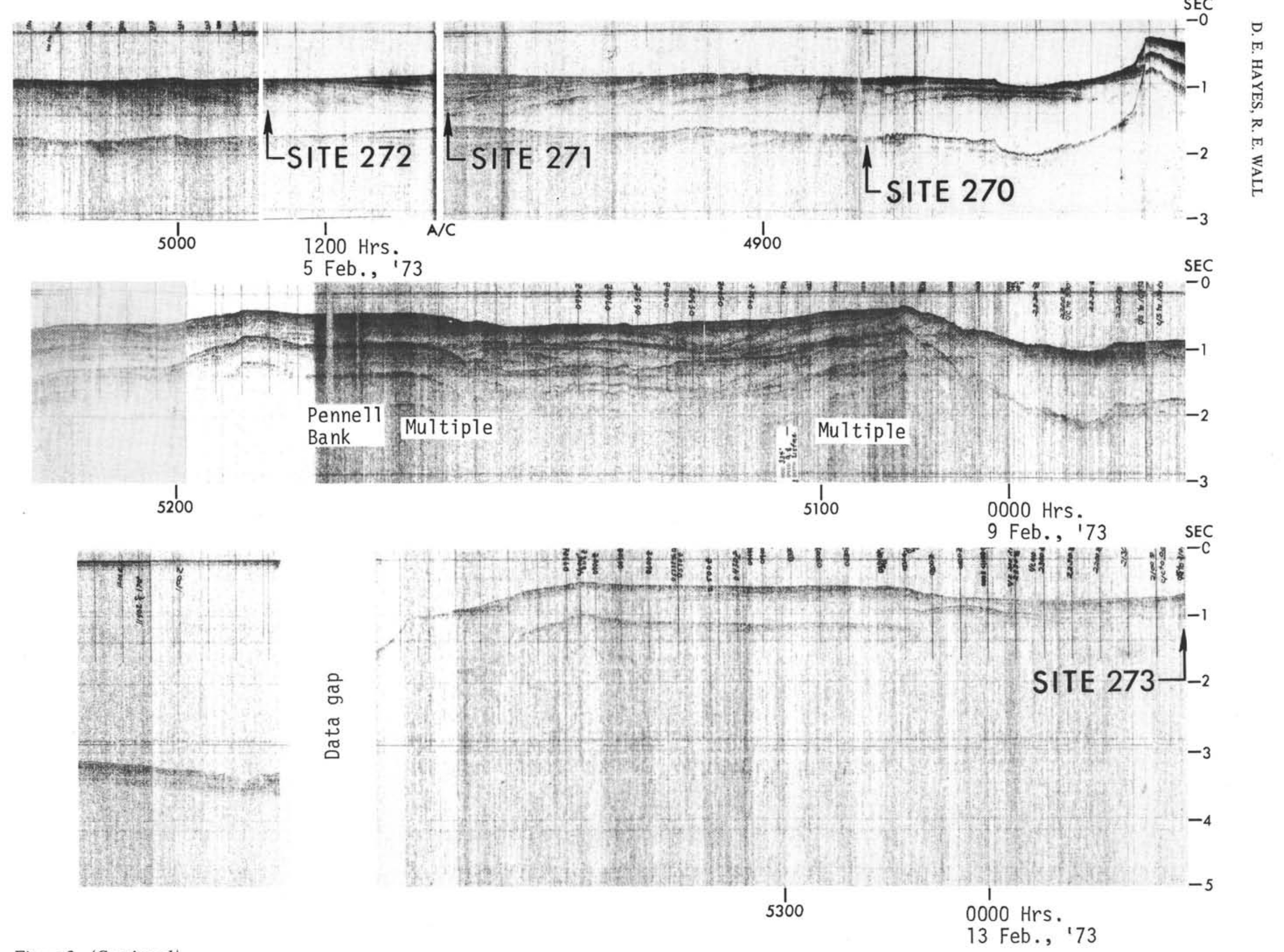

Figure 3. (Continued). 

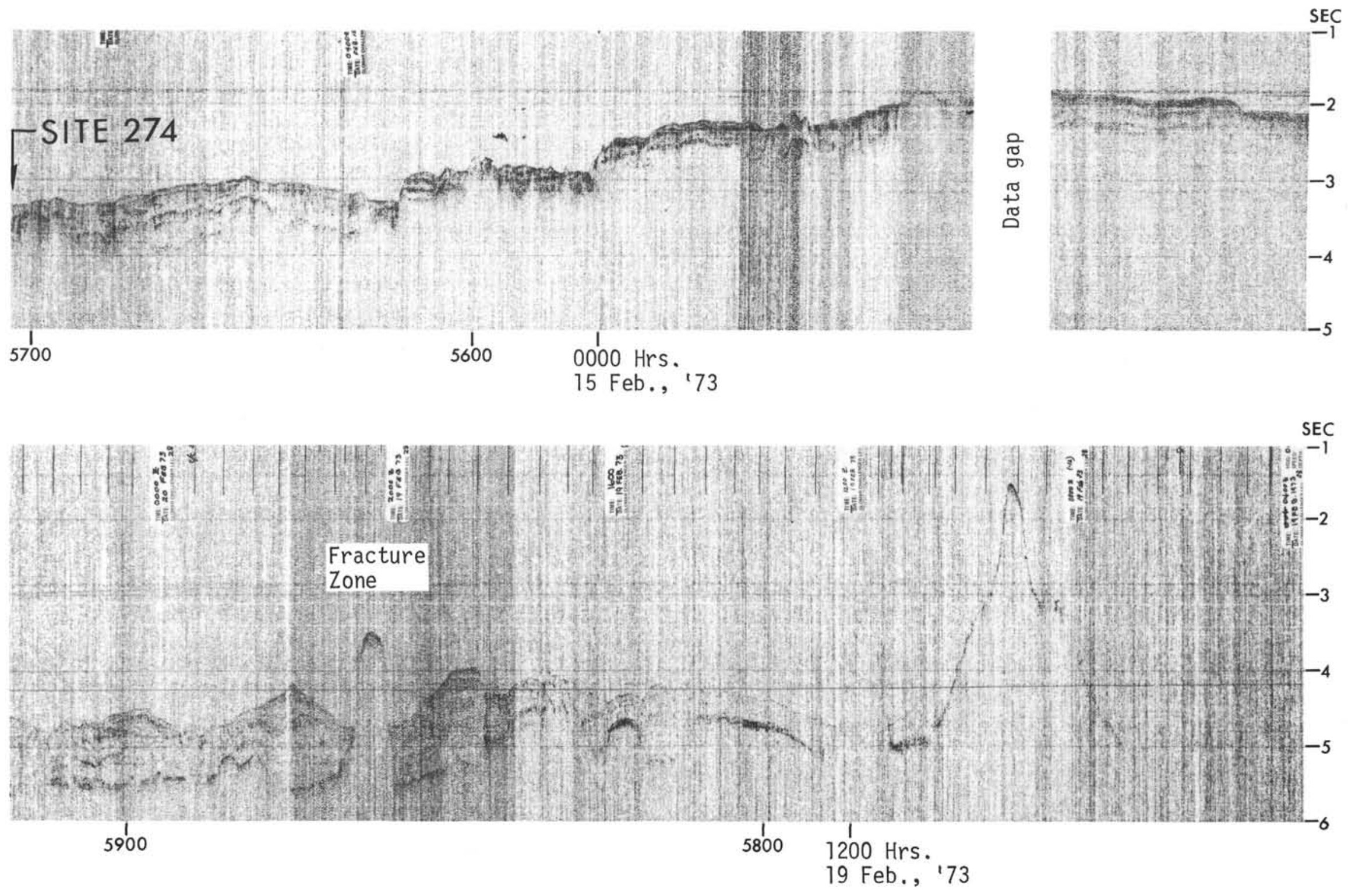


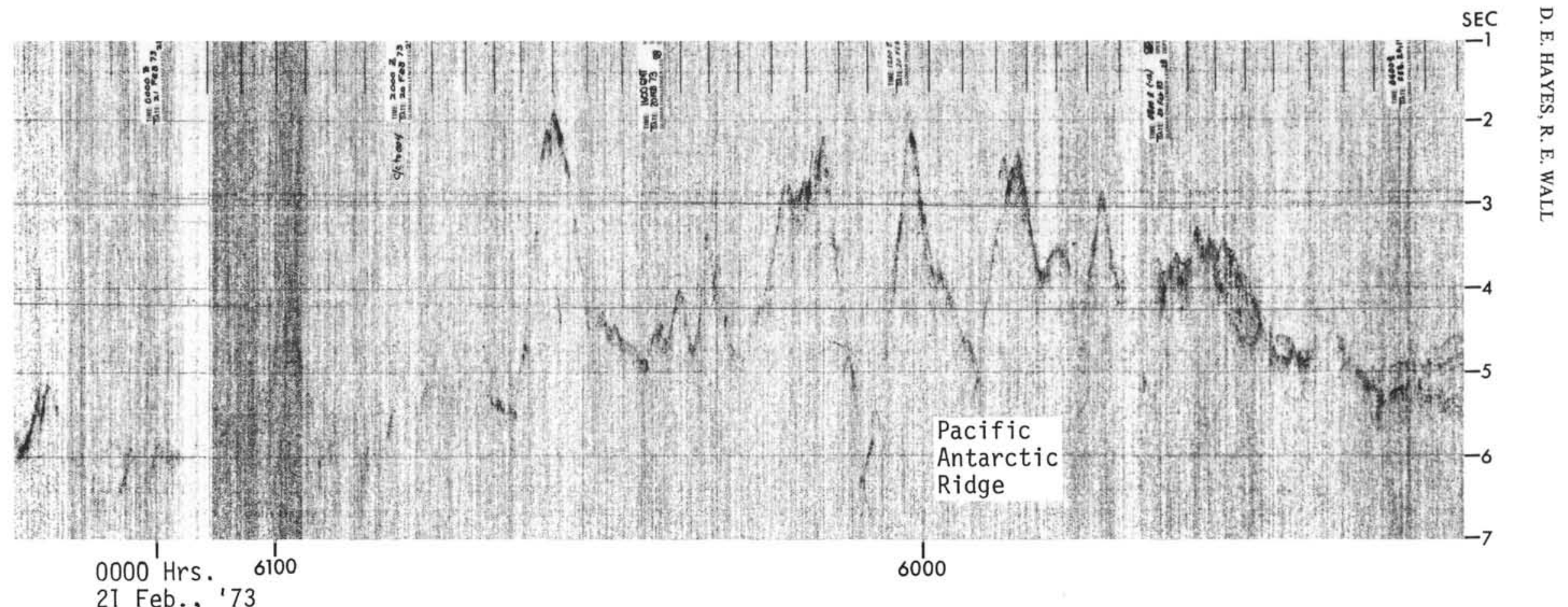

2I Feb. 173

SEC

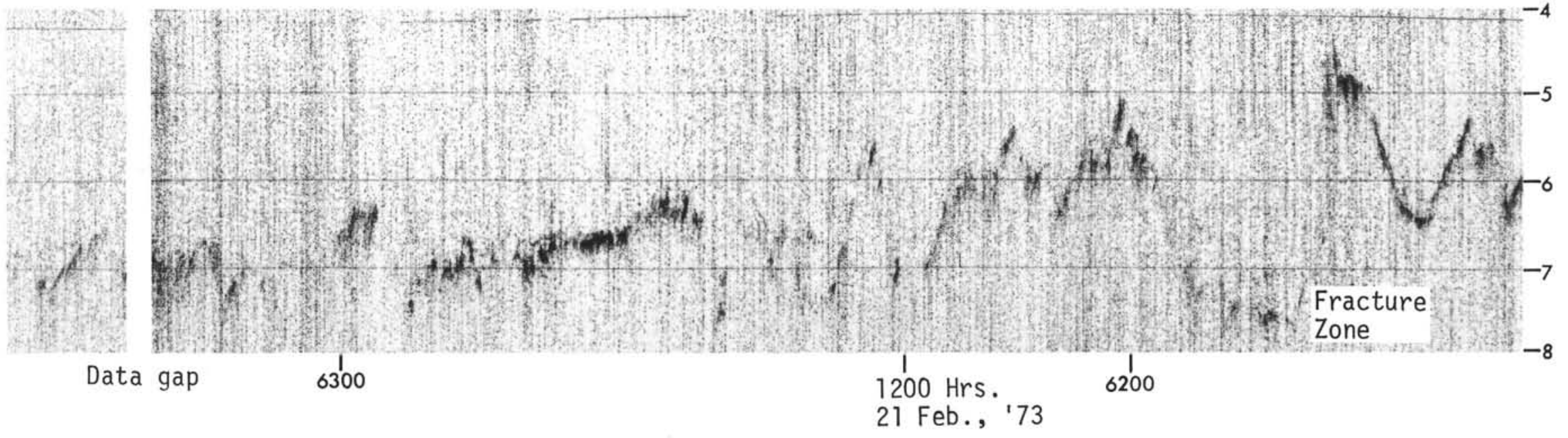

Figure 3. (Continued). 

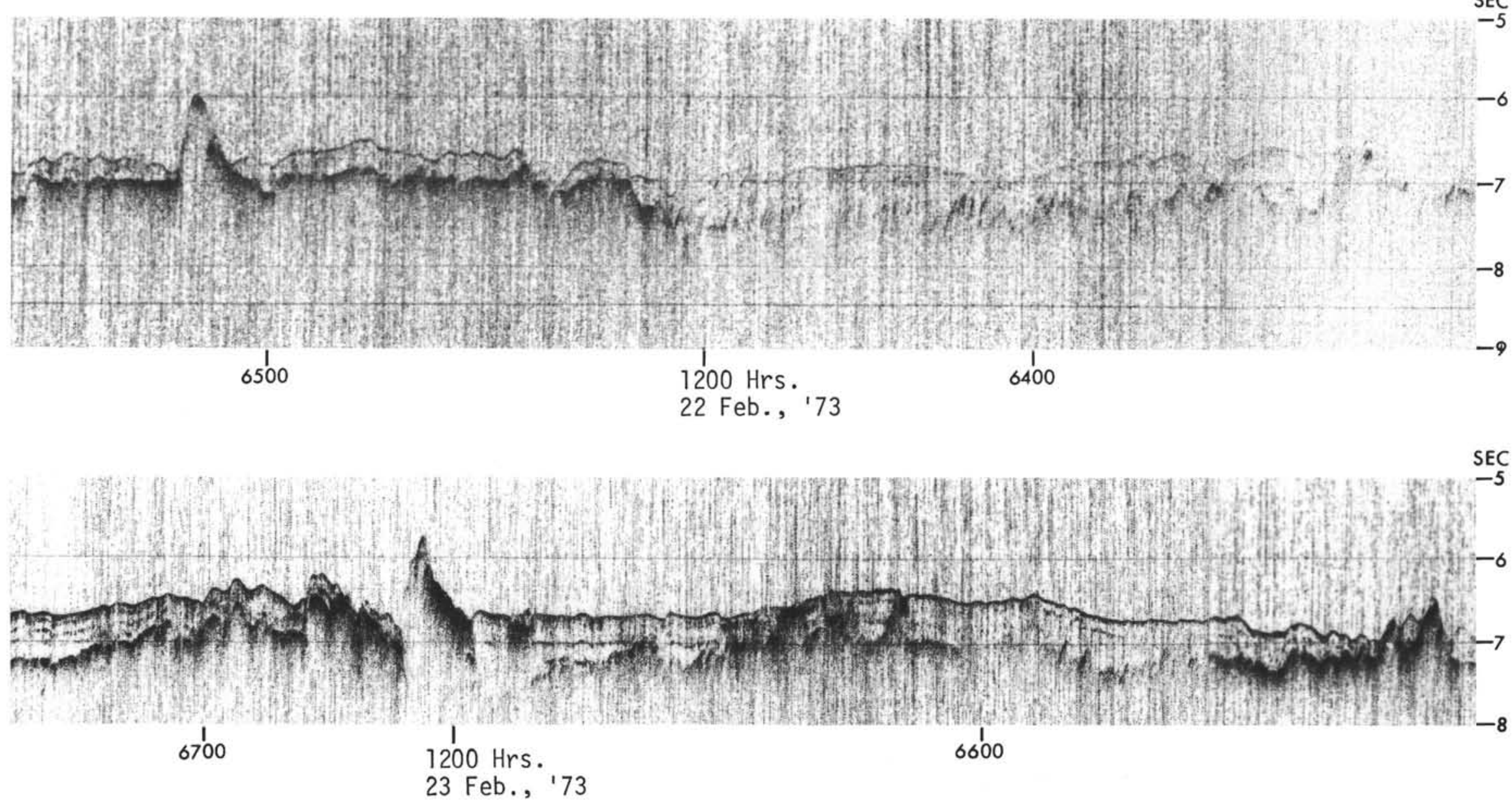

Figure 3. (Continued). 


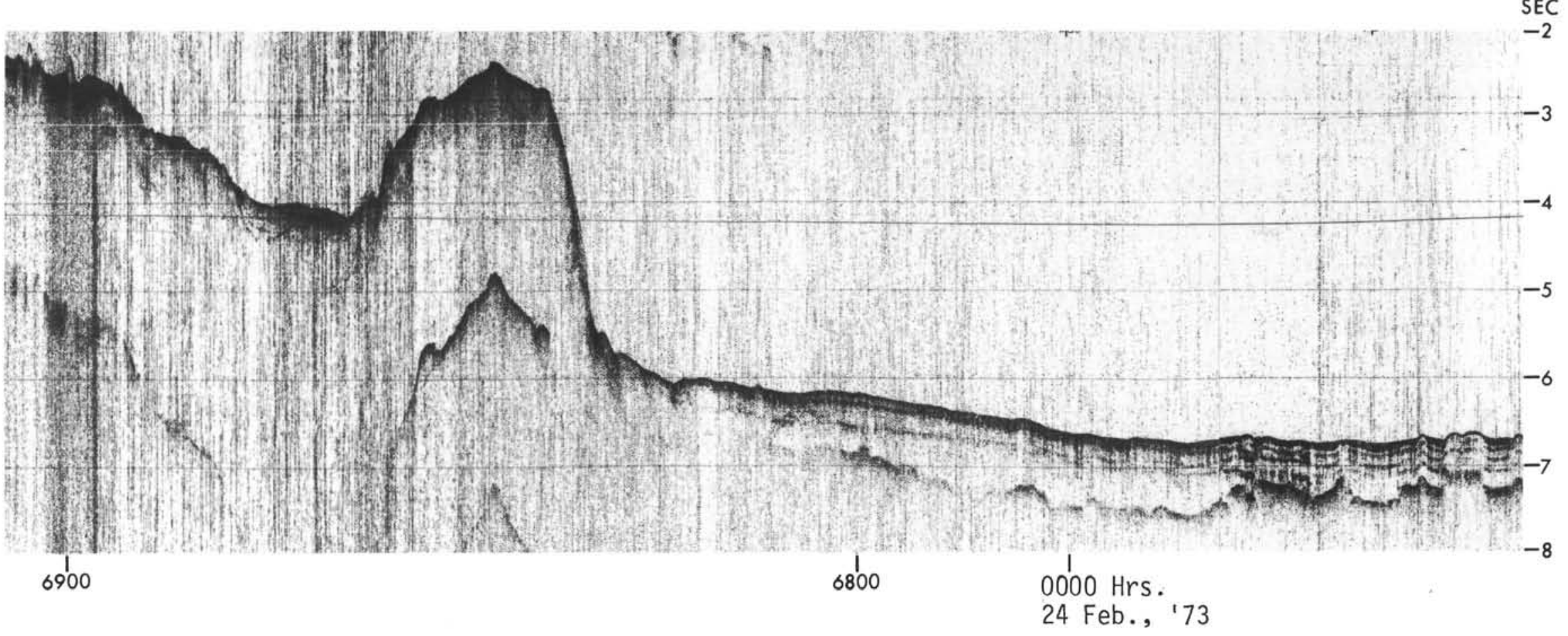

SEC

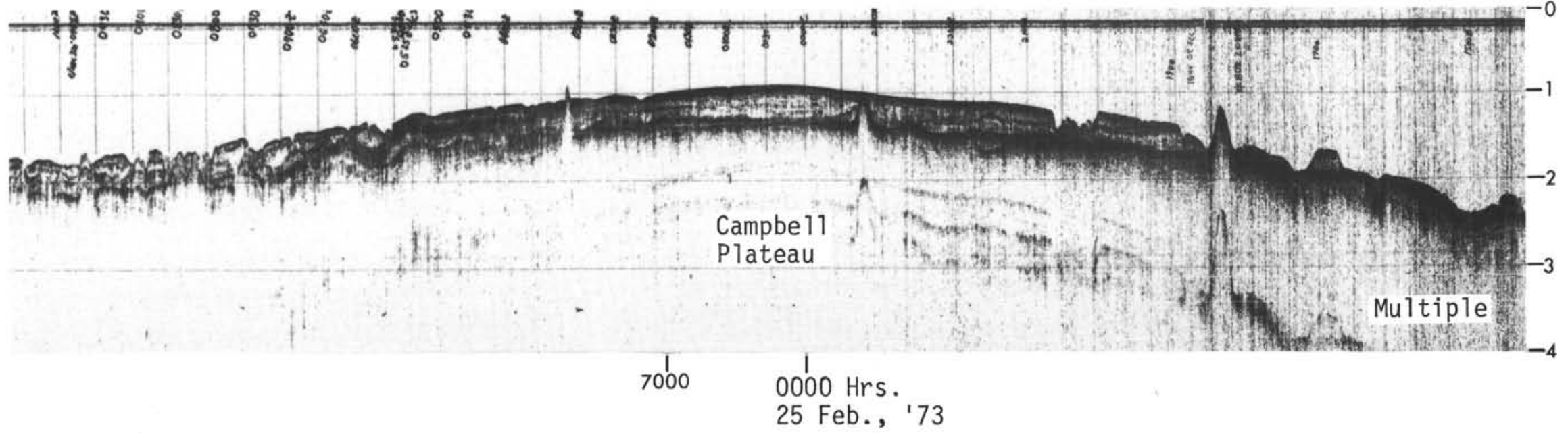

Figure 3. (Continued). 


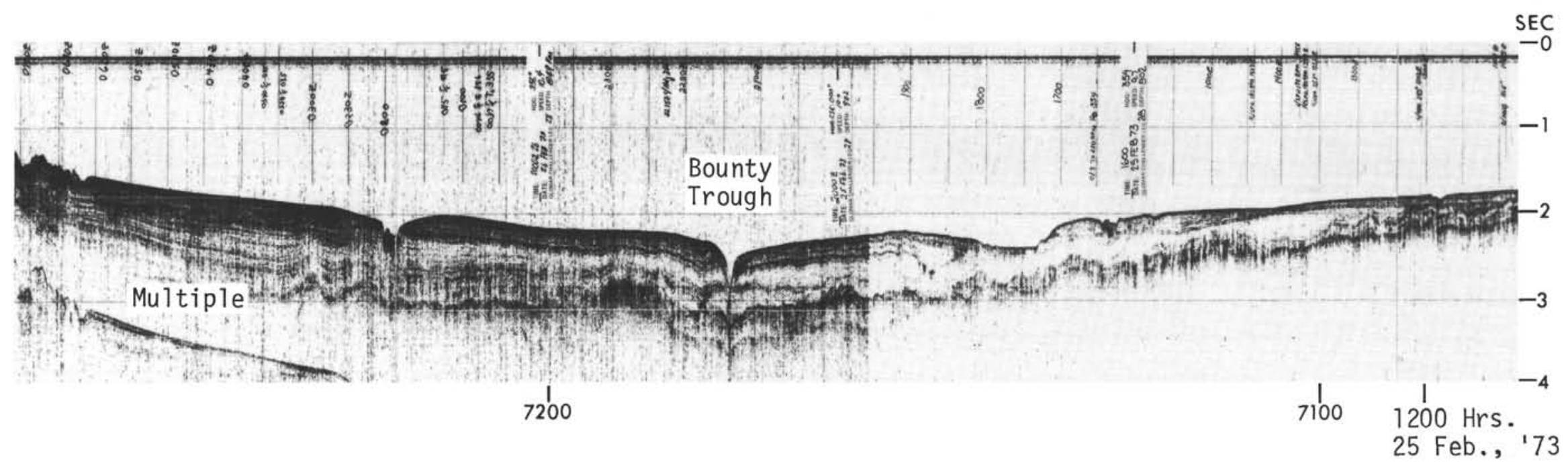

Arrive

Christchurch, N. Z.

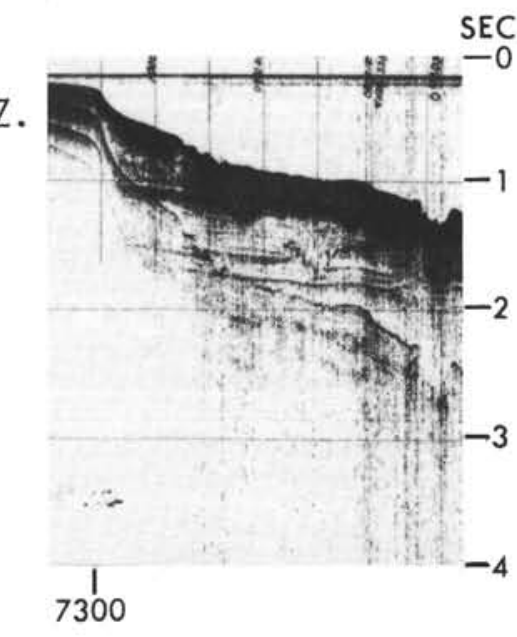

